\title{
Petrography, multi-element geochemistry and multivariate statistical analysis of residual laterites from the Wa-Lawra Belt, NW Ghana: Implications for identifying pathfinder elements of gold
}

Emmanuel Daanoba Sunkari ( $\nabla$ edsunkari@umat.edu.gh )

University of Mines and Technology https://orcid.org/0000-0002-0898-2286

Samuel Edem Kodzo Tetteh

University of Mines and Technology https://orcid.org/0000-0003-2367-9266

Moses Sumbobo

Azumah Resources Ghana Limited

Yilmaz Demir

Recep Tayyip Erdoğan University

\section{Research Article}

Keywords: Regolith, laterites, geochemical anomaly, gold, multivariate statistical analysis, petrography

Posted Date: January 20th, 2022

DOI: https://doi.org/10.21203/rs.3.rs-1279747/v1

License: (c) (1) This work is licensed under a Creative Commons Attribution 4.0 International License. Read Full License 


\section{Abstract}

The Wa-Lawra greenstone belt is located in northwest Ghana and is largely dominated by Birimian metavolcanics, volcaniclastics, and metasediments with some intrusive suites. These rocks are capped by mineralized laterites in most localities, especially in the Kunche area. Previously, regolith materials such as laterites and soils from mixed sources were used to identify pathfinder elements of gold in the belt. However, in-situ (residual) laterites will better represent their underlying formations than transported laterites because transported laterites may contain extraneous sources of element enrichment caused by pollution, which is unrelated to gold mineralization. Therefore, in this study, petrographic studies of residual laterites and statistical analyses of trace element geochemical data of the residual laterites were performed to identify the pathfinder elements of gold in the Wa-Lawra greenstone belt. Six fresh residual laterite samples were used for the petrographic studies, which revealed the dominance of quartz, amphibole, clinopyroxene, hematite, goethite, magnetite, sphalerite, and pyrite. These minerals contribute Fe, S, Ca, Zn, and other elements to the laterites. The geochemical data of 12 residual laterite samples were used for statistical analysis. P-P plots revealed deviations from the normal distribution and outliers in the dataset. Spearman's correlation revealed that Cu, Ag $\mathrm{As}, \mathrm{Pb}, \mathrm{Fe}$, and $\mathrm{S}$ have moderate-strong positive correlation with Au. Hierarchical cluster analysis revealed that there are 3 multi-element associations; a) Fe, $\mathrm{Pb}, \mathrm{Mn}, \mathrm{S}, \mathrm{Co}, \mathrm{Au}, \mathrm{Cr}, \mathrm{Cu}, \mathrm{Ni}, \mathrm{Ag} ; \mathrm{b}) \mathrm{Ti}, \mathrm{Zr}, \mathrm{Sr}, \mathrm{Ca}$, and c) Rb, $\mathrm{Y}, \mathrm{Zn}, \mathrm{As}$. Factor analysis shows that the occurrence of $\mathrm{Pb}, \mathrm{Cu}, \mathrm{Ag}$, and $\mathrm{As}$ is directly related to the occurrence of $\mathrm{Au}$. Thus, the best multi-element association of $\mathrm{Au}$ for exploration purposes is $\mathrm{Pb}, \mathrm{Cu}, \mathrm{Ag}$, and As similar to the previous findings. Single and multi-element anomaly mapping revealed that geochemical anomalies involving these elements are mainly found around the northern and southern parts of the study area on hills and ridges. The results of this study confirm what has been reported by the previous studies. However, it is recommended that gold exploration in similar terranes should be focused on areas dominated by residual laterites since they will always give a true reflection of geochemical anomalies than transported laterites.

\section{Introduction}

Laterite is a soil type rich in iron and aluminium, which forms mostly in tropical areas and is usually of rusty-red coloration as a result of high iron oxide content (Widdowson, 2009). Based on the source of the material from which they are formed, laterites can be categorized as lateritic duricrust (residual laterites) and transported (detrital) laterites, since some form by the in-situ cementation of weathered products while others form via the cementation of weathering products from different sources (Anand et al., 2001). Laterites result from intense and prolonged weathering of the underlying bedrock. That is, in climates of a tropical nature where there is severe in-situ weathering of rocks, these products of weathering that are rich in iron form (Widdowson, 2009). Thus, laterites can be said to be a relevant group of iron and aluminium rich products of weathering together with other products such as paleosols and ferricretes (Sunkari et al., 2019). Laterites have a vertical extent up to $20 \mathrm{~m}$ and a horizontal extent that is laterally vast, thereby forming blankets or layers of few to several thousands of square kilometers, which are relatively resistant to weathering (Widdowson, 2009).

Laterites are becoming a focus in tropical regions during mineral exploration programs, in many parts of the world because they serve as a suitable sampling medium for discovering hidden or concealed gold in laterite-capped tropical terranes. The advances in laterite geochemistry have resulted in critical approaches for the interpretation of anomalies in laterite samples (Anand, 2001). Since it was used by Mazzucchelli and James (1966) for geochemical prospecting within the enclave of Western Australia, trace element geochemistry utilizing laterites has proven to be an important tool (Anand et al., 2001). To comprehend the mechanisms of geochemical dispersion in mineral exploration, there is the need to ascertain how trace elements behave in lateritic materials, especially in terranes of deeply weathered regolith (Nude et al., 2012). According to Ghezelbash et al. (2019), statistical analysis and geostatistical methods can be used to delineate anomalous patterns related to mineralization. Rate (2018) also indicated that statistical tools are useful in determining patterns, groupings, and associations in geochemistry. This is possible because variables in geochemistry have a multivariate behavior as well as a regionalized nature (Ghezelbash et al., 2019).

Multivariate statistical methods can reveal geochemical signatures which can be linked to the hidden geology, weathering, and processes that have occurred or are occurring, and the associated mineralization within a given area after a sampling program (Sunkari et al., 2019). Nude et al. (2012) said that to show deviation from the normal distribution, various descriptive statistics are determined for the elements under investigation. These are the minimum, maximum, range, mean, median, and standard deviation. The deviation shown by these statistics is attributed to high values due to outliers (Nude et al., 2012). Moreover, when analyzing the dataset obtained to identify relationships between gold and the elements selected, correlation analysis, factor analysis with principal component analysis (PCA) method, and hierarchical cluster analysis (HCA) are used (Nude et al., 2012). Correlation measures the association between two variables while HCA calculates the similarity/dissimilarity between elements and clusters them together based on their similarities (Lermi and Sunkari, 2020). Factor Analysis extracts principal components from the dataset and presents observations in 2-3 dimensional charts, which show the degree of similarity between variables and make interpretations easier (Sunkari et al., 2020).

The Wa-Lawra greenstone belt, located in Ghana, belongs to the Birimian supra-crustal domain of the Paleoproterozoic age which has been folded, metamorphosed, and intruded by granitoids (Amponsah et al., 2015). Of all the greenstone belts in Ghana, this belt is the only N-S trending belt contrasting the approximately NE-SW trend of the rest (Arhin and Nude, 2009). The greenstone belts in Ghana are known to host several important gold mines (Nude et al., 2012). However, it is difficult to establish gold reserves within the Wa-Lawra Belt although it has identical lithologies, mineralization styles, and structures when compared to the other greenstone belts found in the southwestern parts of the country (Arhin et al., 2015). Arhin et al. (2015) attributed this difficulty to the regolith profile in such complex terranes since it is difficult to replicate successful gold exploration in areas of deeply weathered terranes with extensive cover of ferruginous materials and vast detrital sediments. Unaware of this fact, in northern Ghana, many exploration firms still carry out gold analysis on crushed and raw field samples (Sunkari et al., 2019).

The Wa-Lawra Belt shows great promise for commercially viable gold mineralization but several attempts in exploring and exploiting the resource have been largely unsuccessful over the years (Waller et al., 2012). Sunkari et al. (2019) indicated that most companies exploring for gold in the belt use methods drawn from those used in the southern parts of Ghana without consideration of the fact that there is a contrast between the climatic conditions prevailing in northern

Page 2/21 
and southern parts of the country. Savannah climate exists in northern Ghana leading to a landscape that is a deeply weathered terrane with abundant laterites (Fig. 1). Sunkari et al. (2019) mentioned that there is a great thickness of cemented residual and transported laterites in savannah-dominated regions unlike the terranes existing in many rainforest areas. The landscape contrasts between the savannah regions and rainforest regions (Fig. 1) are a result of changes to differences in climate, the nature of biological activities in both regions, topography variations, and the mode of lateritization (Arhin, 2013). This implies that how elements are mobilized and/or dispersed by different geochemical processes in northern Ghana varies from that of southern Ghana and hence, different methods of mineral exploration, as well as different methods of interpretation of geochemical signature are required in the Wa-Lawra Belt (Sunkari et al., 2019). Hence, several researchers used statistical methods to identify pathfinder elements of gold in the Wa-Lawra Belt. Nude et al. (2012) identified indicator elements for $\mathrm{Au}$ to be $\mathrm{Pb}, \mathrm{Ag}, \mathrm{As}, \mathrm{Cu}, \mathrm{Fe}$, and $\mathrm{Mn}$, using soil samples from the Wa-Lawra Belt. Sunkari et al. (2019) also identified Pb, Cu, As, and $\mathrm{Ag}$ as indicator elements for Au using laterites from the Wa-Lawra Belt. These studies agree that laterites are the best geochemical sampling material in studies carried out purposefully to find the indicator elements of Au in deeply weathered regolith terranes and the most useful pathfinder elements of Au in the area are $\mathrm{As}, \mathrm{Ag}, \mathrm{Cu}$, and $\mathrm{Pb}$. In both cases, both residual and transported laterites were used for the analysis. The petrography of the laterites was also not studied. Generally, in-situ (residual) laterites will better represent their underlying formations than transported soils. Also, transported laterites may contain extraneous sources of element enrichment caused by pollution, which is unrelated to gold mineralization.

There is, therefore, a gap in the previous works done in the area. The gap this study seeks to fill is to determine the minerals associated with the laterites and the implications when only residual laterites are used for the analysis. This brings the following research questions to the forefront: Will the residual laterites be more accurate and effective in determining pathfinder elements of gold or will similar results be obtained as before? What are the rock-forming minerals and ore minerals associated with the formation of the residual laterites? What will be the implications for gold exploration in the area? This study is therefore aimed at conducting petrographic studies, multi-element geochemical analysis, and multivariate statistical analysis of residual laterites in the Wa-Lawra Belt. The implications for identifying pathfinder elements of gold in the area will also be elucidated.

\section{Geology And History Of Gold Prospection}

The Wa-Lawra greenstone belt is located in northwest Ghana (Fig. 2a). This study is focused on Kunche area in the Nadowli-Kaleo District of the Upper West Region in the Wa-Lawra greenstone belt (Fig. 2a). The area is dominated by Birimian metavolcanics and volcaniclastics, Birimian metasediments and some intrusive granitoids (Sunkari and Zango, 2018). Metamorphosed lavas and pyroclastic rocks namely basalts, andesite, rhyolites, and dolerites which are intruded in some places by gabbro are the major metavolcanic rocks in the area (Nude et al., 2012). The dominant metasedimentary rocks in the area include phyllite, sericite-schist and meta-greywacke, which are intruded in some places by dykes of felsic and mafic nature (Arhin and Nude, 2009). Magmatic bodies and porphyritic granitoids that have generally been classified into two broad categories intrude the metavolcanic and metasedimentary rocks (Nude et al., 2012). These intrusive granitoids include Belt-type hornblende-rich granitoids that are closely associated with the volcanic rocks and mica-rich Basin-type granitoids, which are found in the metasedimentary units (Baratoux et al., 2011; Sunkari and Zango, 2018). The rocks in the area have been isoclinally folded during the Eburnean orogeny which occurred around $2.1 \mathrm{Ga}$ and have a $50^{\circ}$ or more dip trend N-NNE to S-SSW (Fig. 2b). According to Griffis et al. (2002), the Eburnean orogeny is associated with shear-zone mineralization in the Wa-Lawra greenstone belt.

The Birimian Greenstone Belts found in Ghana hosts orogenic gold formed by hydrothermal fluids from metamorphism (Griffis et al., 2002). The mineralization is associated with mesothermal quartz veins found in both Upper and Lower Birimian rocks (Griffis et al., 2002). Amponsah et al. (2015) along with many other authors acknowledged that the veins associated with Au mineralization are quartz veins where quartz has a dark gray color. The ore minerals which are associated with this mineralization style which are common in the area include pyrite, arsenopyrite, chalcopyrite, sphalerite, and galena while the associated gangue minerals include calcite, chlorite, ankerite, and tourmaline (Amponsah et al., 2015).

Most rock units in the Kunche area host quartz veins, but those mineralized are usually seen to occur with sections of faulting and shearing found at contact zones between the Upper and Lower Birimian rock units (Nude et al., 2012). Waller et al. (2012) revealed that there is a shear zone known as the Kunche Shear Zone within which the quartz veins formed and that this Kunche Shear Zone contains interfused phyllites and greywackes, which have undergone intense brecciation due to the crustal shortening that deformed and disturbed the veins. These veins are associated with wall rock alteration types namely propylitic alteration marked by chlorite and carbonate alteration products, silicification which increases the amount of quartz and chert found in host rocks, and sericitization in which plagioclase is replaced leaving behind alteration products of sericite and quartz (Amponsah et al., 2015). Hence, a collection of secondary minerals, formed due to the action of hydrothermal fluids, is associated with the mineralized veins and these minerals include muscovite, chlorite, epidote, carbonates, and graphite (Nude et al., 2012).

Gold discovery in the area was reported as far back as 1935 (Nude et al., 2012). There have been small-scale mining activities in the area even before 1935. Ghana Geological Survey and their Soviet counterpart through collaborative geological mapping and prospecting identified in 1960 and confirmed the gold occurrence reported by Junner (Nude et al., 2012). An exploration firm called BHP Minerals carried out geochemical surveys on a regional scale and collected stream sediments using Bulk Leach and Extractable Gold method, over the entire area of the Wa-Lawra belt in the year 1990 (Nude et al., 2012 ). Geochemical anomalies were observed after analysis of the stream and soil samples collected but these anomalies were regarded to be economically unattractive when they were compared to those produced in southern and western Ghana terranes. Ashanti-AGEM Ltd. had a prospecting license for the whole Wa-Lawra Belt (Nude et al., 2012). Reconnaissance surveys involving samples from media such as rocks, laterites, anthills, and mounds of termites, and soils were conducted. Geological field mapping and satellite imagery were also done over the belt. These surveys revealed multiple zones with geochemical anomalies. Thus, surveys of a follow-up nature were carried out over these zones delineating four neighboring areas to which the most attention should be given, namely Boiri, Babile, Chereponi North, and Chereponi South (Nude et al., 2012). Azumah Resources Limited started fresh geochemical surveying activities in 2006 and has since uncovered several potential targets of geochemical nature, related to mineralization (Nude et al., 2012).

\section{Materials And Methods}




\subsection{Sample collection and geochemical analysis}

For this study fresh residual laterite samples were obtained from the Kunche area, following the same protocols used by Sunkari et al. (2019). Fifteen samples were obtained from old pits, in-situ materials on the surface, and holes of diameter $30 \mathrm{~cm}$ dug by a hoe within the plateaus and hills. Due to the influence of organic material in most places, the first $20 \mathrm{~cm}$ of material was not included during the sampling. These samples were used for petrographic analysis. Only 6 of these samples were selected for the analysis. Field photographs of the laterite exposures are shown in Figure 3.

Also, secondary laterite geochemical data were obtained from earlier research that studied the spatial distribution and trace element geochemistry of laterites in the Kunche area, and their implication for gold exploration targets in NW Ghana as carried out by Sunkari et al. (2019). In the said study, Sunkari et al. (2019) collected a total of 67 laterite samples from hills and plateaus in Kunche, all near gold prospects. The samples were obtained from old pits, in-situ materials on the surface, and holes of diameter $30 \mathrm{~cm}$ dug by a hoe within the plateaus and hills (Sunkari et al., 2019). $2 \mathrm{~kg}$ laterite samples were taken at each of the 67 sample points and sent to the geochemical laboratories of Azumah Resources Limited for geochemical analysis. The samples were analyzed to obtain concentrations of iron, sulfur, manganese, calcium, titanium, chromium, molybdenum, nickel, cobalt, copper, thorium, rubidium, strontium, lead, zinc, and antimony via XRF analysis. The majority of the samples had concentrations of molybdenum, thorium, zinc, and antimony below the detection limit, hence, these elements were generally not utilized for the geostatistical analysis carried out by Sunkari et al. (2019). Concentrations of silver, arsenic, and gold were obtained via the ICP-MS technique, which gave a $5 \mathrm{ppb}$ and $0.01 \mathrm{ppm}$ limit of detection for gold, silver, and arsenic, respectively. For this study, however, only the results of lateritic duricrust (residual laterite) samples, constituting 12 out of the 67 samples, were considered.

\subsection{Petrographic analysis}

Six samples (KL01, KL02, KL03, KL04, KL05, and KL06) were selected for the preparation of thin and polished sections. These samples were cut and slabbed to a size of $26 \mathrm{~mm}$ by $48 \mathrm{~mm}$. Abrasive papers of grit size $60-1200$ were used to grind the best surface of the slabs by hand. Glass slides were also prepared by grinding/lapping one surface of the slide using the 600 meshpowder. The slabs meant for the preparation of thin sections were then warmed and prepared surface of the bonded to the smooth surface of the slides using epoxy resin.. Curing was then done for about 30 minutes. Bulk sample removal was then done by a rock cutting machine to obtained sections of thin thickness. These were finally thinned by abrasive powders of grit size $600-1200$ till the thickness of the sections was reduced to $30 \mu \mathrm{m}$. On the other hand, the slabs meant for polished sections were, polished using $1 \mu \mathrm{m}$ and $0.25 \mu \mathrm{m}$ diamond paste and lubricant (1:3, Petrol: Kerosene) on a special polishing cloth.

To identify the minerals and their associations within the residual laterites from the Kunche area, the thin and polished sections were studied under the microscope at the petrology laboratory of the Geological Engineering Department of the University of Mines and Technology (UMaT), Tarkwa. LEICA DM750P and LEICA DM2700P microscopes with Leica MC 120HD digital camera attached and linked to a computer were used for studying the thin sections under transmitted light. LEICA DM2700P with Leica MC 120HD digital camera attached was used to study the polished sections under reflected light to identify the opaque minerals and the petrographic characteristics within the residual laterites from the Kunche area.

\subsection{Data processing and statistical methods}

\subsubsection{P-P plots}

The cumulative probability plots (P-P plots) are used to determine whether the variable distribution is consistent with a given and known specified distribution. For a normally distributed dataset, the scatters should fall on or tightly close to the normal distribution line (Gao and Chik, 2013). For this study, P-P plots were used to check whether or not the data set is normally distributed before multivariate statistical analysis.

\subsubsection{Spearman's correlation}

The relationship between any two variables in geochemistry can be determined taking into consideration the multivariate and regionalized character of the variables using the two-tailed Spearman's correlation method (Sunkari et al., 2019). Correlation measures the linear association between two variables to indicate if the value of one variable reliably changes in response to changes in the value of the other variable (Debrah, 2013). Correlation can be classified based on the behavior of a variable as the value of another variable increase as follows:

1. Positive correlation implies the variable tends to increase with the other variable;

2. A negative correlation implies the variable decreases with an increase in the other variable and

3. No correlation means the variable is indifferent to the other variable.

Correlation is denoted by $r$ where $-1 \leq r \leq 1$. Positive values show a positive linear correlation, negative values indicate a negative linear correlation while a 0 value means no correlation (Debrah, 2013). The closer the value is to 1 or -1 , the stronger the correlation. In many studies with several variables, the correlation between the variables is often computed in a tabular form as the correlation matrix (Debrah, 2013). That is, correlation is negligible between 0.00 0.30 , low between $0.30-0.50$, moderate for $0.50-0.70$, high for 0.70-0.90, and very high between 0.90-1.00.

\subsubsection{Centered log-ratio (CLR) transformation}

Since geochemical data usually deviates from the normal, the application of Centered Log-Ratio (CLR) Transformation lowers the gap that exists between the minimum and maximum contents within the multi-element dataset obtained from XRF and ICP-MS analysis (Zhao et al., 2015). The CLR is mathematically 
expressed as:

$$
\operatorname{CLR}(x)=\left(\log \left(\frac{x 1}{g(x)}\right), \ldots, \log \left(\frac{x N}{g(x)}\right)\right)
$$

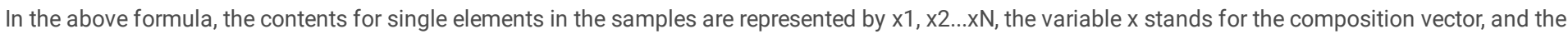
geometric mean is given by $\mathrm{g}(\mathrm{x})$.

\subsubsection{Hierarchical cluster analysis (HCA) and factor analysis}

In analyzing the dataset obtained to identify relationships between gold and the elements as well as their possible sources, factor analysis with principal component analysis method as the extraction criterion and hierarchical cluster analysis (HCA) were used in the SPSS environment. The results of the HCA were presented using dendrograms. The dendrograms show the steps used by the software in obtaining the solution, the multi-element clusters, and the distances separating these multi-element clusters known as the squared Euclidean distance (Nude et al., 2012). Nude et al. (2012) summarized the HCA procedure by stating that the similarity or disparity existing between $\mathrm{X}$ number of elements is calculated. Afterward, the clustering of two elements is done on the condition that a stated agglomeration criterion will be lowered when the two elements cluster in combination. This clustering forms a class within which the two elements are found. Further, two elements or elemental classes are clustered under the above condition by similarly determining the similarity or contrast that exists between the earlier formed class and $\mathrm{N}-2$ remaining elements. This process continues until all the elements have been clustered.

During the factor analysis, principal component analysis method was applied in which principal components (factors) were obtained from the data, where each factor shows a certain process or groups of them responsible for how parameter values vary spatially (Sunkari et al., 2020). To obtain the number of components to extract, the Kaiser Criterion was used. The Kaiser Criterion extracts only principal components having eigenvalues of 1 or more than 1 . Scree plots show the number of components while the covariance matrix indicates the index of similarity (Nude et al., 2012).

\subsubsection{Delineation of geochemical anomalies}

To separate anomaly from background values anomaly thresholds were calculated such that those values that are more than the threshold are the anomalies of interest in geochemistry. Reimann et al. (2005) proposed a means of finding the anomaly threshold. This method was used for this study. If T represents the threshold value, med represents the median of a given element and MAD represents the median absolute deviation, then the following formula is used;

$$
T=\text { med }+2 M A D
$$

The median absolute deviation of a dataset represents the average distance between each data point and the mean and that MAD gives an idea about the variability in a dataset, which is a measure of how dispersed the data is (Reimann et al., 2005). MAD is determined by the formula given that $x_{i}$ represent the concentration of elements;

$M A D=$ median $\mid x i-$ median $(x i) \mid$

(3)

MAD is instrumental in determining geochemical halos in a single element (Sunkari et al., 2019). Dispersal patterns or signatures can better be defined by combining more than one indicator element when compared to the single element technique (Reis et al., 2001). This combination method is known as the multi-element halos technique. The multi-element halo technique was used together with the computed thresholds to determine geochemical halos associated with the existence of enriched pathfinder elements related to Au mineralization in the Kunche area. The formula used is given as;

$$
H(X+Y)=\left(\frac{X_{1}}{X_{0}}+\frac{Y_{1}}{Y_{0}}\right) ;\left(\frac{X_{2}}{X_{0}}+\frac{Y_{2}}{Y_{0}}\right) ; \ldots ;\left(\frac{X_{N}}{X_{0}}+\frac{Y_{N}}{Y_{0}}\right)
$$

$X_{1}, X_{2}, \ldots, X_{N}$ are concentrations of $X$ in samples $1,2, \ldots, N . Y_{1}, Y_{2}, \ldots, Y_{N}$ are concentrations of $Y$ in samples $1,2, \ldots, N$. $X_{0}$ and $Y_{0}$ are threshold values of $X$ and $Y$ elements.

To generate maps that show single element and multi-element anomaly distributions, Geographic Information System (GIS) application software, ArcMap, version 10.8 was used. These maps were generated to understand spatial patterns. Using Inverse Distance Weighting (IDW) Method, the single and multielement threshold results aided in producing the geochemical anomaly map of the study area. According to Sabbaghi and Hassan (2020), the inverse distance weighting method is widely utilized as a technique of interpolation. It is computationally easy and uses the weighted distances between points with known values and those with unknown values to determine the unknown values. Since only 12 samples are representing lateritic duricrusts within the secondary data, the IDW method was used as kriging usually would require at least 30 samples.

\section{Results}

\subsection{Petrography of the residual laterites}

\subsubsection{Thin sections}


The microscopic studies of the residual laterites reveal a hypidiomorphic to granoblastic texture, for many of the sections, dominated by subhedral-anhedral amphibole, clinopyroxene, quartz, goethite, hematite, and some opaque minerals (Fig. 4a-f). The amphiboles observed generally have 2nd-3rd order brown interference colors while clinopyroxenes have 2 nd-3rd order blue-indigo interference colors (Fig. $4 \mathrm{a}$ and b). The amphiboles appear to be prismatic and are deformed (with multiple fractures and pits) resulting in partial alteration to clinopyroxene (Fig. 4a). Goethite has a more reddish-brown coloration under transmitted light when compared with hematite (Fig. 4a) and results from the oxidation of the residual laterites at the surface since the laterites are exposed to more water conditions. However, both goethite and hematite appear to form the matrix together with quartz.

Due to the deformation in the samples, there are some shear zones observed along the crystal boundaries of amphiboles, which are generally filled with recrystallized quartz and late-stage clinopyroxenes that also overprint the amphiboles (Fig. 4b). The sample that displays a granoblastic texture is dominated by subhedral granular quartz with relatively minor occurrences of clinopyroxene and hornblende (Fig. 4c). There are also fractures in some places, which are filled with recrystallized quartz (Fig. 4d). Rims of amphibole around clinopyroxene with multiple fractures, shearing, and pits are also common (Fig. 4e). Significant deformation of the crystals, particularly of quartz, clinopyroxene, and amphibole, is observed (Fig. 4e). Amphibole became unstable under nearsurface low-temperature conditions and was altered to clinopyroxene within the core of the amphibole (Fig. 4e). A rear occurrence of orthopyroxene with its characteristic octagonal form, though very much deformed is observed (Fig. 4f). The deformation has resulted in the crystal appearing as a very dark-yellow crystal (Fig. 4f).

\subsubsection{Ore microscopy}

Microscopic studies under reflected light show hematite, magnetite, goethite, pyrite, and sphalerite as the dominant minerals within the residual laterites (Fig. 5a-f). Selvages and blebs of sphalerite appear to grow within masses of hematite (Fig. 5a). These selvages and blebs of sphalerite, with a bright yellowish-white appearance, are found mostly at the edges of hematite and are distinguished from creamy-white to pale yellow colored pyrite (Fig. 5a). Magnetite masses with grey appearance are separated by some matrix material. These masses are euhedral to subhedral tabular grains with several pits showing some deformation (Fig. 5b). Hematite has a whitish grey coloration and is distinguished from goethite by the intense and bright reddish-brown coloration of goethite (Fig. 5c). Goethite appears to replace hematite (Fig. 5c), corroborating the observation under transmitted light that the oxidation of hematite led to the formation of goethite within the residual laterites from the Kunche area. Magnetite is found as a stout grey and deformed octahedral crystal within hematite (Fig. 5c).

Pyrite is mostly in the form of blebs within hematite and sheared quartz (Fig. 5d). Pyrite is found to occur in close proximity and association with shattered quartz (Fig. 5d). This may imply that pyrite was emplaced by hydrothermal fluids after the shearing of the quartz veins in the Kunche area, before lateritization. Sphalerite is found within hematite as a subhedral crystal and blebs and as selvages along the boundaries of deformed hematite (Fig. 5 e). Goethite and recrystallized quartz occur within masses of hematite and within these same masses of hematite are late phase sphalerite blebs (Fig. $5 f$ ). Pyrite oxidized to hematite while goethite was produced by the hydration and oxidation of hematite (Fig. 5f).

\subsection{Multi-element geochemistry}

The multi-element geochemistry of the residual laterite samples from the Kunche area is presented in Table 1 and summarized in Table 2. The mean concentrations and range (minimum and maximum) of concentrations for the elements of most interest are respectively given as follows: $32.1 \%$ and $8.27-$ 46.1 wt \% for Fe; 0.36\% and 0.19-0.49 wt \% for S; 734 ppm and 215-1439 ppm for Mn, 32.4 ppm and 0.00-155 ppm for Ni, 77.5 ppm and 14.0-411 ppm for Cu, 42.3 ppm and 6.00-71.0 ppm for Pb, 75.9 ppm and 0.00-147 ppm for As, 5.50 ppm and 0.02-62.0 ppm for Ag, 95.7 ppb and 18.0-196 ppb for Au and 19.1 ppm and 0.00-90.0 ppm for $\mathrm{Zn}$. In a box and whisker plot which involves $\mathrm{Fe}, \mathrm{S}, \mathrm{Pb}, \mathrm{Mn}, \mathrm{Ni}, \mathrm{As}, \mathrm{Cu}, \mathrm{Zn}, \mathrm{Au}$, and $\mathrm{Ag}$, Mn is observed as the most dominant element in the residual laterites since its whisker lies well above that of all other elements (Fig. 6). Sulfur has the least dominance by its extremely small box and whisker relative to the other elements (Fig. 6). This may imply that the laterites were derived from the basic Birimian metavolcanic rocks underlying them.

Table 1

Multi-element geochemical data of residual laterite samples from the Kunche area (Sunkari et al., 2019; concentrations of S and Fe in \%, Au in ppb and $t$

\begin{tabular}{|c|c|c|c|c|c|c|c|c|c|c|c|c|c|c|c|c|c|}
\hline $\begin{array}{l}\text { Sample } \\
\text { ID }\end{array}$ & $\begin{array}{l}\text { X } \\
\text { (UTM) }\end{array}$ & Y (UTM) & $\mathrm{Fe}$ & $S$ & Mn & $\mathrm{Ca}$ & $\mathrm{Ti}$ & $\mathrm{Cr}$ & $\mathrm{Ni}$ & Co & $\mathrm{Cu}$ & $\mathbf{R b}$ & $\mathrm{Sr}$ & $\mathrm{Zr}$ & $\mathrm{Y}$ & $\mathrm{Pb}$ & $\mathrm{Zn}$ \\
\hline MPL008 & 527153 & 1148297 & 30.6207 & 0.3533 & 273 & 609 & 2298 & 420 & 0 & 0 & 33 & 22.5 & 39.8 & 282 & 4 & 40 & 0 \\
\hline MPL009 & 527202 & 1148227 & 23.9433 & 0.2736 & 1439 & 708 & 1727 & 379 & 155 & 561 & 104 & 42.9 & 14.2 & 98 & 12.5 & 49 & 90 \\
\hline MPL013 & 527367 & 1147821 & 43.4478 & 0.4531 & 1027 & 1258 & 1858 & 492 & 54 & 1569 & 411 & 24.9 & 20.3 & 178 & 6.5 & 71 & 13 \\
\hline MPL014 & 527397 & 1147608 & 43.6221 & 0.4248 & 1075 & 1400 & 1398 & 539 & 41 & 1197 & 72 & 25.6 & 8.9 & 63 & 5.7 & 70 & 23 \\
\hline MPL037 & 526345 & 1146218 & 31.5666 & 0.2695 & 356 & 829 & 1259 & 743 & 0 & 609 & 19 & 11.7 & 8.6 & 135 & 0 & 30 & 0 \\
\hline MPL053 & 527089 & 1145006 & 29.0631 & 0.376 & 919 & 553 & 1832 & 471 & 70 & 1794 & 80 & 25.8 & 6.8 & 91 & 8.6 & 28 & 50 \\
\hline MPL054 & 526859 & 1145000 & 40.8079 & 0.4058 & 764 & 1153 & 3068 & 973 & 0 & 0 & 22 & 24.3 & 13.5 & 204 & 6.1 & 62 & 0 \\
\hline MPL055 & 526822 & 1145143 & 19.5527 & 0.3288 & 932 & 1387 & 2319 & 415 & 40 & 935 & 26 & 25.2 & 14 & 174 & 5.4 & 19 & 16 \\
\hline MPL056 & 526820 & 1145378 & 39.3995 & 0.3945 & 215 & 925 & 3167 & 291 & 0 & 1275 & 14 & 17.6 & 9.5 & 248 & 0 & 49 & 0 \\
\hline MPL064 & 527020 & 1147072 & 46.0857 & 0.4912 & 595 & 1076 & 1631 & 1027 & 0 & 243 & 81 & 17.3 & 5.1 & 47 & 6.9 & 54 & 0 \\
\hline MPL065 & 527057 & 1148058 & 8.2692 & 0.19 & 639 & 2507 & 2038 & 388 & 29 & 274 & 36 & 34.2 & 35.8 & 192 & 11.1 & 6 & 37 \\
\hline MPL066 & 527358 & 1147948 & 29.2493 & 0.4036 & 577 & 514 & 2372 & 511 & 0 & 548 & 32 & 19.7 & 8.4 & 199 & 3.4 & 29 & 0 \\
\hline
\end{tabular}


Table 2

Summary statistics of untransformed element concentrations obtained from residual laterite samples in the Kunche area (concentrations of Fe and S in \%, Au in ppb, and the rest in ppm).

\begin{tabular}{|lllllllll|}
\hline Element & No. & Minimum & Maximum & Mean & STD & Variance & Skewness & Kurtosis \\
\hline $\mathrm{Fe}$ & 12 & 8.27 & 46.1 & 32.1 & 11.3 & 127 & -0.72 & 0.20 \\
\hline $\mathrm{Sn}$ & 12 & 0.19 & 0.49 & 0.36 & 0.09 & 0.01 & -0.63 & 0.06 \\
\hline $\mathrm{Ca}$ & 12 & 215 & 1439 & 734 & 363 & 131931 & 0.294 & -0.32 \\
\hline $\mathrm{Ti}$ & 12 & 514 & 2507 & 1077 & 549 & 301382 & 1.65 & 3.69 \\
\hline $\mathrm{Cr}$ & 12 & 291 & 1027 & 554 & 236 & 55677 & 1.26 & 0.51 \\
\hline $\mathrm{Ni}$ & 12 & 0.00 & 155 & 32.4 & 46.1 & 2123 & 1.90 & 4.17 \\
\hline $\mathrm{Co}$ & 12 & 0.00 & 1794 & 750 & 601 & 361399 & 0.41 & -1.01 \\
\hline $\mathrm{Cu}$ & 12 & 14.0 & 411 & 77.5 & 109 & 11903 & 3.03 & 9.79 \\
\hline $\mathrm{Rb}$ & 12 & 11.7 & 42.9 & 24.3 & 8.12 & 66.0 & 0.95 & 1.72 \\
\hline $\mathrm{Sr}$ & 12 & 5.10 & 39.8 & 15.4 & 11.3 & 127 & 1.54 & 1.37 \\
\hline $\mathrm{Zr}$ & 12 & 47.0 & 282 & 159 & 73.3 & 5366 & -0.03 & -0.87 \\
\hline $\mathrm{Y}$ & 12 & 0.00 & 12.5 & 5.85 & 3.80 & 14.5 & 0.08 & -0.14 \\
\hline $\mathrm{Pb}$ & 12 & 6.00 & 71.0 & 42.3 & 20.5 & 419 & -0.16 & -0.83 \\
\hline $\mathrm{Zn}$ & 12 & 0.00 & 90.0 & 19.1 & 27.9 & 778 & 1.76 & 3.03 \\
\hline $\mathrm{As}$ & 12 & 0.00 & 147 & 75.9 & 55.1 & 3037 & 0.21 & -1.82 \\
\hline $\mathrm{Au}$ & 12 & 18.0 & 196 & 95.7 & 56.4 & 3177 & 0.50 & -0.54 \\
\hline $\mathrm{Ag}$ & 12 & 0.02 & 62.0 & 5.50 & 17.8 & 317 & 3.46 & 12.0 \\
\hline $\mathrm{Nal}$ & 12.03 & 597 & 356868 & 0.64 & -0.21 \\
\hline
\end{tabular}

\subsection{Statistical analysis}

The ore minerals associated with $\mathrm{Au}$ in the area include sulfides such as galena, sphalerite, pyrite, chalcopyrite, and arsenopyrite (Amponsah et al., 2015). This means the elements of interest considered for the statistical analyses are $\mathrm{Au}, \mathrm{Fe}, \mathrm{S}, \mathrm{Pb}, \mathrm{Cu}, \mathrm{Zn}, \mathrm{As}$, and Ag.

\subsubsection{P-P plots}

P-P plots of $\mathrm{Cu}, \mathrm{Pb}, \mathrm{Fe} \mathrm{Ag}, \mathrm{Au}$, and As in Figure 7 show deviation from the normal distribution and skewness, which both point to several groups within the concentrations for all elements. This is because regional geochemical data seldom shows a normal distribution. This means the raw dataset arises from more than one association of elements, and this can be linked to different geochemical processes (Zuo, 2011).

\subsubsection{Correlation analysis}

To evaluate the correlation between the elements of interests, Spearman's correlation was used. This method was selected because unlike Pearson's correlation, there is no requirement of normality and hence it is a nonparametric statistic. Spearman's correlation revealed a strong positive correlation between Fe and S ( $r=0.84), \mathrm{Mn}$ and $\mathrm{Rb}(\mathrm{r}=0.76), \mathrm{Zr}$ and Ti $(r=0.81), \mathrm{Pb}$ and $\mathrm{Fe}(\mathrm{r}=0.86), \mathrm{Pb}$ and $\mathrm{S}(\mathrm{r}=0.75), \mathrm{S}$ and Au $(r=0.71)$, as well as Ag and Au $(r=$ $0.80)$ (Table 3). Moderate positive correlation exists between Fe and $\mathrm{Cr}(r=0.66), \mathrm{S}$ and $\mathrm{Cr}(r=0.56), \mathrm{Mn}$ and $\mathrm{Cu}(r=0.65), \mathrm{Rb}$ and $\mathrm{Cu}(r=0.51), \mathrm{Zr}$ and $\mathrm{Sr}(\mathrm{r}=$ 0.55), $\mathrm{Zn}$ and As ( $r=0.57)$, Cu and Au ( $r=0.57)$, as well as $S$ and $\mathrm{Ag}(r=0.51)$ (Table 3). 
Table 3

Two-tailed Spearman's correlation matrix with $r \leq-0.5$ and $r \geq 0.5$ Boldened.

\begin{tabular}{|c|c|c|c|c|c|c|c|c|c|c|c|c|c|c|c|c|c|c|}
\hline & $\mathrm{Fe}$ & $S$ & Mn & $\mathrm{Ca}$ & $\mathrm{Ti}$ & $\mathrm{Cr}$ & $\mathrm{Ni}$ & Co & $\mathrm{Cu}$ & $\mathbf{R b}$ & $\mathrm{Sr}$ & $\mathrm{Zr}$ & $Y$ & $\mathrm{~Pb}$ & $\mathrm{Zn}$ & As & $\mathrm{Au}$ & $\mathrm{Ag}$ \\
\hline $\mathrm{Fe}$ & 1.00 & & & & & & & & & & & & & & & & & \\
\hline$S$ & 0.84 & 1.00 & & & & & & & & & & & & & & & & \\
\hline $\mathrm{Mn}$ & -0.07 & 0.12 & 1.00 & & & & & & & & & & & & & & & \\
\hline $\mathrm{Ca}$ & 0.13 & 0.06 & 0.36 & 1.00 & & & & & & & & & & & & & & \\
\hline $\mathrm{Ti}$ & -0.22 & 0.03 & -0.36 & -0.08 & 1.00 & & & & & & & & & & & & & \\
\hline $\mathrm{Cr}$ & 0.66 & 0.56 & -0.01 & 0.01 & -0.37 & 1.00 & & & & & & & & & & & & \\
\hline $\mathrm{Ni}$ & 0.34 & 0.32 & -0.59 & -0.61 & 0.14 & 0.41 & 1.00 & & & & & & & & & & & \\
\hline Co & 0.14 & 0.20 & 0.21 & 0.01 & 0.14 & -0.22 & 0.24 & 1.00 & & & & & & & & & & \\
\hline $\mathrm{Cu}$ & 0.10 & 0.30 & 0.65 & 0.06 & -0.49 & 0.04 & -0.30 & -0.01 & 1.00 & & & & & & & & & \\
\hline $\mathrm{Rb}$ & -0.53 & -0.30 & 0.76 & 0.27 & -0.08 & -0.48 & -0.59 & 0.18 & 0.51 & 1.00 & & & & & & & & \\
\hline $\mathrm{Sr}$ & -0.36 & -0.39 & 0.13 & 0.34 & 0.28 & -0.55 & -0.58 & 0.05 & 0.08 & 0.41 & 1.00 & & & & & & & \\
\hline $\mathrm{Zr}$ & -0.20 & -0.19 & -0.56 & -0.15 & 0.81 & -0.36 & 0.13 & 0.07 & -0.55 & -0.21 & 0.55 & 1.00 & & & & & & \\
\hline Y & -0.26 & -0.41 & 0.18 & 0.07 & -0.34 & -0.35 & -0.19 & -0.06 & 0.25 & 0.36 & 0.00 & -0.33 & 1.00 & & & & & \\
\hline $\mathrm{Pb}$ & 0.86 & 0.75 & 0.26 & 0.18 & -0.16 & 0.40 & 0.01 & 0.23 & 0.30 & -0.18 & -0.02 & -0.12 & -0.13 & 1.00 & & & & \\
\hline $\mathrm{Zn}$ & -0.18 & -0.22 & -0.19 & -0.76 & -0.06 & -0.08 & 0.40 & -0.19 & -0.01 & -0.01 & -0.33 & -0.07 & 0.41 & -0.15 & 1.00 & & & \\
\hline As & 0.04 & 0.27 & -0.18 & -0.71 & -0.02 & -0.05 & 0.46 & -0.05 & 0.43 & -0.02 & -0.35 & -0.10 & 0.05 & -0.04 & 0.57 & 1.00 & & \\
\hline $\mathrm{Au}$ & 0.37 & 0.71 & 0.34 & -0.14 & -0.02 & 0.47 & 0.38 & 0.28 & 0.57 & 0.12 & -0.31 & -0.27 & -0.26 & 0.34 & -0.02 & 0.46 & 1.00 & \\
\hline $\mathrm{Ag}$ & 0.11 & 0.51 & 0.25 & -0.07 & 0.04 & 0.47 & 0.19 & -0.19 & 0.47 & 0.07 & -0.38 & -0.27 & -0.22 & 0.01 & -0.09 & 0.40 & 0.80 & 1.00 \\
\hline
\end{tabular}

Strong to moderate negative correlation is seen to occur between $\mathrm{Mn}$ and $\mathrm{Ni}(\mathrm{r}=-0.59)$, Ca and Ni $(r=-0.61)$, Fe and Rb $(r=-0.53), \mathrm{Ni}$ and Rb ( $r=-0.59)$, Cr and $\mathrm{Sr}(\mathrm{r}=-0.55), \mathrm{Ni}$ and $\mathrm{Sr}(\mathrm{r}=-0.58), \mathrm{Mn}$ and $\mathrm{Zr}(\mathrm{r}=-0.56), \mathrm{Cu}$ and $\mathrm{Zr}(\mathrm{r}=-0.55), \mathrm{Ca}$ and $\mathrm{Zn}(\mathrm{r}=-0.76)$, as well as Ca and As ( $\mathrm{r}=-0.71)(\mathrm{Table} 3)$. For the elements of interest, Au shows strong positive correlation with $\mathrm{Ag}(r=0.80)$ and $\mathrm{S}(r=0.71)$, and moderate positive correlation with $\mathrm{Cu}(r=0.57)(\mathrm{Table} 3)$. For the remaining selected elements, Au correlates weakly and positively with $\mathrm{Fe}(r=0.37), \mathrm{Pb}(r=0.34)$, and As $(r=0.46)$ (Table 3). The occurrence of Au and Zn is likely to be a result of different geochemical processes since the correlation between Au and $\mathrm{Zn}$ is negatively negligible with $r=-0.02($ Table 3 ).

\subsubsection{Factor analysis for untransformed data}

For the untransformed data, $89.38 \%$ of the total variance is defined by six factors with eigenvalues more than 1 (Table 4 ). Factor 1 explains $29.48 \%$ of the total variance (Table 4) and represents Mn-Ni-Y-Rb-Zn multi-element association (Fig. 8a). It correlates positively with Mn, Ni, Y, Rb, and Zn. According to Deng et al. (2010), such an association may be due to lithologic control and associated metamorphic-hydrothermal fluids that permeated the rocks from which the laterites formed. Under favorable conditions, this led ultimately to the formation of ore minerals such as sphalerite, the ore mineral of $\mathrm{Zn}$.

Table 4

Total variance explained for the raw dataset

\begin{tabular}{|lllllll|}
\hline \multicolumn{3}{|l|}{ Total Variance Explained for Raw Dataset } \\
\hline Factor & Initial Eigenvalues & & \multicolumn{3}{l|}{ Extraction Sums of Squared Loadings } \\
\cline { 2 - 7 } & Total & $\%$ of Variance & Cumulative \% & Total & $\%$ of Variance & Cumulative \% \\
\hline 1 & 5.31 & 29.48 & 29.48 & 5.31 & 29.48 & 29.48 \\
\hline 2 & 4.44 & 24.66 & 54.14 & 4.44 & 24.66 & 54.14 \\
\hline 3 & 1.95 & 10.81 & 64.95 & 1.95 & 10.81 & 64.95 \\
\hline 4 & 1.74 & 9.67 & 74.62 & 1.74 & 9.67 & 74.62 \\
\hline 5 & 1.57 & 8.73 & 83.35 & 1.57 & 8.73 & 83.35 \\
\hline 6 & 1.08 & 6.03 & 89.38 & 1.08 & 6.03 & 89.38 \\
\hline
\end{tabular}


Table 5

Rotated component matrix for untransformed data with strong positive loadings boldened.

\begin{tabular}{|c|c|c|c|c|c|c|}
\hline \multicolumn{7}{|c|}{ Rotated Component Matrix for Raw Data } \\
\hline & \multicolumn{6}{|l|}{ Factor } \\
\hline & 1 & 2 & 3 & 4 & 5 & 6 \\
\hline $\mathrm{Fe}$ & -0.302 & 0.922 & -0.106 & 0.032 & 0.027 & 0.074 \\
\hline S & -0.265 & 0.839 & -0.046 & 0.270 & 0.044 & 0.264 \\
\hline $\mathrm{Mn}$ & 0.853 & 0.200 & -0.274 & -0.060 & 0.146 & 0.123 \\
\hline $\mathrm{Ca}$ & 0.056 & -0.343 & -0.029 & -0.758 & -0.172 & 0.225 \\
\hline $\mathrm{Ti}$ & -0.148 & 0.148 & 0.839 & 0.052 & -0.070 & -0.221 \\
\hline $\mathrm{Cr}$ & -0.285 & 0.482 & -0.421 & -0.012 & -0.653 & -0.016 \\
\hline $\mathrm{Ni}$ & 0.929 & -0.038 & -0.156 & 0.020 & 0.279 & 0.009 \\
\hline Co & 0.088 & 0.186 & -0.207 & -0.006 & 0.910 & 0.157 \\
\hline $\mathrm{Cu}$ & 0.211 & 0.358 & -0.046 & -0.136 & 0.357 & 0.731 \\
\hline $\mathrm{Rb}$ & 0.940 & -0.225 & 0.147 & -0.129 & -0.062 & 0.103 \\
\hline $\mathrm{Sr}$ & 0.068 & -0.509 & 0.524 & -0.279 & -0.264 & 0.451 \\
\hline $\mathrm{Zr}$ & -0.338 & -0.241 & 0.894 & -0.008 & 0.008 & 0.039 \\
\hline Y & 0.849 & -0.173 & -0.155 & -0.067 & -0.258 & 0.328 \\
\hline $\mathrm{Pb}$ & 0.098 & 0.924 & 0.041 & -0.140 & 0.023 & 0.122 \\
\hline $\mathrm{Zn}$ & 0.924 & -0.233 & -0.185 & 0.019 & 0.162 & -0.053 \\
\hline As & 0.201 & -0.002 & -0.221 & 0.796 & -0.240 & 0.384 \\
\hline $\mathrm{Au}$ & 0.167 & 0.446 & -0.234 & 0.341 & 0.059 & 0.666 \\
\hline $\mathrm{Ag}$ & -0.194 & -0.132 & 0.106 & 0.743 & 0.000 & -0.009 \\
\hline $\begin{array}{l}\text { Extr } \\
\text { Rota } \\
\text { a. R }\end{array}$ & $\begin{array}{l}\text { ction Me } \\
\text { ion Meth } \\
\text { tation co }\end{array}$ & $\begin{array}{l}\text { hod: Prin } \\
\text { d: Varim } \\
\text { verged in }\end{array}$ & $\begin{array}{l}\text { pal Com } \\
\text { x with K } \\
10 \text { iterati }\end{array}$ & iser Norr & $\begin{array}{l}\text { alysis } \\
\text { alization }\end{array}$ & \\
\hline
\end{tabular}

Factor 2 explains $24.66 \%$ of the total variance (Table 4) and represents Fe-Pb-S multi-element association (Fig. 8a). The elements correlating with this factor are essentially from sulfide ore minerals including pyrite and galena reflecting the mineralogical association of Au in the area. The presence of these sulfides is explained by the host rocks in the area, from which the residual laterites formed, which are mostly volcaniclastic. This factor is a result of dispersion facilitated by water (hydromorphic dispersion) of sulfide-bearing minerals, supported by the strong positive correlation between Fe and $\mathrm{S}(\mathrm{r}=0.84$ ) and $\mathrm{Pb}$ and $S(r=0.75)$. Riedinger et al. (2017) indicated that the enrichment of Fe and S occurs in environments that are dominated by Fe-oxides, supported by the existence of Fe-oxides and, inorganic carbonate particles characterized by internal concentric laminations that are spherical to sub-spherical with diameters larger than $2 \mu \mathrm{m}$ known as pisoliths.

Factor 3 explains $10.81 \%$ of the total variance (Table 4) and represents Zr-Sr-Ti multi-element association (Fig. 8a). Sunkari et al. (2019) indicated that detrital material and wall rocks were responsible for the input of the elements of this factor. A 0.81 correlation between $\mathrm{Zr}$ and Ti points to the same origin and similar geochemical processes in their enrichment. Zr in this factor represents the occurrence of zircon while Ti represents the presence of rutile, an oxide of Ti. Zircon and rutile are accessory minerals in igneous rocks and are common in lateritic terranes, Kunche inclusive.

Factor 4 explains $9.67 \%$ of the total variance (Table 4) and represents Ag-As-Ca multi-element associations (Fig. 8a). It is a sub-factor of factor 3. Ag and As were enriched in Fe-rich zones after they were leached from the primary halo (Sunkari et al., 2019). Ca in this factor shows input from rock-forming minerals, particularly calcic plagioclase known as anorthite. Accordingly, the elements within this factor were sourced from the wall rocks and hydrothermal solutions.

Factor 5 accounts for $8.73 \%$ of the total variance (Table 4) and represents Cr-Co element associations (Fig. 8a). Helba et al. (2020) said that these elements, particularly $\mathrm{Co}$, are indicative of lithologic control. Therefore, these elements were sourced from the mafic rocks found within the metavolcanic rocks within the area. Factor 6 accounts for $6.03 \%$ of the total variance (Table 4) and represents Au-Cu element association (Fig. 8a). This factor represents input from hydrothermal solutions and wall rocks. That is, $\mathrm{Au}$ and $\mathrm{Cu}$ were deposited under appropriate conditions by hydrothermal solutions which pervaded the wall rocks. Both factors 5 and 6 are sub-groups of factor 4 .

\subsubsection{Factor analysis for the transformed dataset}


$83.29 \%$ of the total variance is defined by 5 factors with eigenvalues greater than 1 (Table 6). Factor 1 accounts for $26.52 \%$ of the total variance (Table 6 ) and represents $\mathrm{Pb}$-Co-Fe-S multi-element associations (Fig. 8b). Elements within this factor result from two sources. Fe, $\mathrm{Pb}$, and $\mathrm{S}$ are from sulfide ore minerals and were enriched by the hydromorphic processes. This agrees with factor 2 of the untransformed data. Fe and $\mathrm{S}$ in any factor represent the dominance of Feoxides. Cobalt on the other hand results from mafic host rocks in the area (lithogenic effect inferred from factor 5 of the untransformed data) (Helba et al., 2020). Thus, this factor shows both hydromorphic dispersion and lithogenic control.

Table 6

Rotated component matrix for centered log-ratio transformed dataset.

\begin{tabular}{|lllllll|}
\hline \multicolumn{7}{|l|}{ Total Variance Explained for Transformed Dataset } \\
\hline \multirow{2}{*}{ Factor } & Initial Eigenvalues & & \multicolumn{3}{l|}{ Extraction Sums of Squared Loadings } \\
\cline { 2 - 7 } & Total & $\%$ of Variance & Cumulative \% & Total & $\%$ of Variance & Cumulative \% \\
\hline 1 & 4.77 & 26.52 & 26.52 & 4.77 & 26.52 & 26.52 \\
\hline 2 & 3.66 & 20.35 & 46.86 & 3.66 & 20.35 & 46.86 \\
\hline 3 & 2.44 & 13.54 & 60.40 & 2.44 & 13.54 & 60.40 \\
\hline 4 & 2.30 & 12.78 & 73.18 & 2.30 & 12.78 & 73.18 \\
\hline 5 & 1.82 & 10.11 & 83.29 & 1.82 & 10.11 & 83.29 \\
\hline
\end{tabular}

Table 7

Total variance explained for centered log-ratio transformed dataset with strong positive loadings

\begin{tabular}{|llllll|}
\hline \multicolumn{6}{c}{ boldened. } \\
\hline $\mathrm{Fe}$ & $\mathbf{0 . 8 7 3}$ & -0.042 & 0.245 & -0.335 & 0.173 \\
\hline $\mathrm{S}$ & $\mathbf{0 . 7 4 6}$ & 0.221 & $\mathbf{0 . 5 0 4}$ & -0.214 & 0.176 \\
\hline $\mathrm{Mn}$ & -0.024 & $\mathbf{0 . 8 3 9}$ & -0.281 & -0.214 & -0.176 \\
\hline $\mathrm{Ca}$ & -0.334 & 0.121 & -0.081 & -0.039 & -0.831 \\
\hline $\mathrm{Ti}$ & 0.039 & -0.138 & 0.307 & $\mathbf{0 . 6 9 8}$ & 0.142 \\
$\mathrm{Cr}$ & 0.051 & 0.020 & 0.385 & -0.736 & -0.049 \\
\hline $\mathrm{Ni}$ & 0.103 & -0.274 & $\mathbf{0 . 8 1 5}$ & -0.026 & -0.278 \\
\hline $\mathrm{Co}$ & $\mathbf{0 . 7 5 1}$ & 0.096 & -0.003 & $\mathbf{0 . 4 1 0}$ & -0.127 \\
\hline $\mathrm{Cu}$ & 0.241 & $\mathbf{0 . 8 2 8}$ & -0.151 & -0.167 & -0.019 \\
\hline $\mathrm{Rb}$ & -0.241 & $\mathbf{0 . 6 8 3}$ & -0.499 & 0.381 & -0.008 \\
\hline $\mathrm{Sr}$ & -0.305 & 0.087 & -0.131 & $\mathbf{0 . 7 0 6}$ & -0.277 \\
\hline $\mathrm{Zr}$ & -0.096 & -0.333 & 0.229 & $\mathbf{0 . 8 4 9}$ & -0.053 \\
\hline $\mathrm{Y}$ & -0.278 & 0.142 & -0.795 & -0.169 & -0.093 \\
\hline $\mathrm{Pb}$ & $\mathbf{0 . 8 9 1}$ & 0.105 & 0.003 & -0.226 & 0.165 \\
\hline $\mathrm{Zn}$ & -0.255 & -0.199 & -0.492 & -0.117 & $\mathbf{0 . 7 3 7}$ \\
\hline $\mathrm{As}$ & 0.118 & 0.199 & 0.050 & -0.024 & $\mathbf{0 . 8 8 3}$ \\
\hline $\mathrm{Au}$ & 0.227 & $\mathbf{0 . 8 4 0}$ & 0.350 & -0.069 & 0.180 \\
\hline $\mathrm{Ag}$ & -0.274 & $\mathbf{0 . 5 2 1}$ & $\mathbf{0 . 6 2 6}$ & -0.103 & 0.383 \\
\hline & & & & & \\
\hline
\end{tabular}

Factor 2 accounts for $20.35 \%$ of the total variance (Table 6) and represents Rb-Mn-Cu-Au multi-element associations (Fig. 8b). Au and Cu were deposited by hydrothermal solutions that circulated in the wall rocks, similar to factor 6 for the untransformed dataset. Mn and Rb are from wall rocks similar to factor 1 for the untransformed dataset. Thus, this factor indicates hydrothermal solution and wall rock inputs. Factor 3 explains $13.54 \%$ of the total variance (Table 6 ) and represents Ag-Ni-Y multi-element associations (Fig. 8b). Ag is from hydrothermal fluids while Ni and $\mathrm{Y}$ are from wall rocks, respectively similar to factors 4 and 1 for the untransformed dataset. Similar to the findings of Sunkari et al. (2019), this factor shows input from wall rocks and hydrothermal fluids as a result.

Factor 4 explains $12.78 \%$ of the total variance (Table 6) and represents Sr-Ti-Cr-Zr multi-element associations (Fig. 8b). Elements Sr, Ti, and Zr were input from detrital material, similar to the findings of Micó et al. (2006) and factor 3 of the untransformed data. Cr is due to a lithogenic effect, similar to factor 5 for the untransformed data. Thus, this factor indicates the lithogenic effect and detrital material input. Factor 5 explains $10.11 \%$ of the total variance (Table 6 ) and represents As-Ca-Zn multi-element associations (Fig. 8b). Ca was input by wall rocks (Ca-rich rock-forming minerals as inferred from factor 3 for the 
untransformed data) while As and Zn were input by hydrothermal sources similar to the findings of Deng et al. (2010). Due to the presence of Zn in this factor, sphalerite can be inferred to occur in the area.

\subsubsection{Hierarchical cluster analysis for untransformed data}

Three clusters representing multi-element associations could be observed in the dendrogram derived from the untransformed dataset (Fig. 9 a). Cluster 1 has a multi-element cluster of $\mathrm{Fe}, \mathrm{S}, \mathrm{Au}, \mathrm{Cr}, \mathrm{Pb}, \mathrm{As}$, and $\mathrm{Ag}$ (Fig. 9a). From this, $\mathrm{As}, \mathrm{Fe}, \mathrm{Pb}$, and $\mathrm{S}$ are from ore minerals such as pyrite, arsenopyrite, and galena while $\mathrm{Au}$ and $\mathrm{Ag}$ are from hydrothermal fluids that pervaded host rocks while $\mathrm{Cr}$ is due to lithogenic control, as observed in factor analysis. Cluster 2 has multielement associations of $\mathrm{Mn}, \mathrm{Ca}, \mathrm{Ni}, \mathrm{Co}, \mathrm{Cu}, \mathrm{Rb}, \mathrm{Y}$, and $\mathrm{Zn}$ (Fig. 9a). Cu and $\mathrm{Zn}$ are from hydrothermal inputs while Mn, Ca, Ni, Co, Rb, and Y are from wall rock inputs. Cluster 3 has multi-element associations of $\mathrm{Sr}$, Ti, and $\mathrm{Zr}$ (Fig. 9a). Elements within this cluster may be derived from wall rocks (host rocks) and transported material as inferred from factor analysis.

\subsubsection{Hierarchical cluster analysis for transformed dataset}

Three clusters representing multi-element associations could be observed in the dendrogram derived from the transformed dataset (Fig. $9 \mathrm{~b})$. Cluster 1 has multi-element associations of $\mathrm{Au}, \mathrm{Fe}, \mathrm{S}, \mathrm{Ag}, \mathrm{Pb}, \mathrm{Mn}, \mathrm{Cr}, \mathrm{Co}, \mathrm{Ni}$, and $\mathrm{Cu}$ (Fig. 9b). Cluster 2 has multi-element associations of Ti, Zr, $\mathrm{Sr}$, and $\mathrm{Ca}$ (Fig. 9b). Cluster 3 has multi-element associations of Rb, As, Y, and Zn (Fig. 9b).

It can be observed that significant similarities exist between cluster 1 for transformed data and cluster 1 for the transformed data, cluster 3 for the untransformed data and cluster 2 for the transformed data, and cluster 2 for the untransformed data and cluster 3 for the transformed data. Cluster 1 is the most common cluster between the untransformed and CLR transformed data where Fe-S-Cr-Pb-Au-Ag is the multi-element association found in both.

\subsection{Single element geochemical anomaly mapping}

Areas with anomalous single element concentrations are shown in Figure 10 (a-e). Blue to light blue areas have low elemental concentrations while yellow to deep red portions are areas with significant single element geochemical anomalies. The gold anomaly map shows areas of anomalous Au concentrations (Fig. 10a). Notable abnormal enrichment of Au can be observed in the northern parts of the area (close to the Kunche gold prospect) and southwestern parts of the area. The central portions of the study area have somewhat moderate Au content. Ag anomaly map of the study area shows that geochemical anomalies are mostly restricted to the northern (close to the gold prospect), central, and the south-eastern parts of the study area (Fig. 10b). The main As geochemical anomaly is restricted to the north-eastern part of the study area (near the gold prospect) (Fig. 10c). Zones of lower but significant geochemical anomalies can also be found dotted around the northern, central, and southern portions of the study area (Fig. 10c). For the Cu anomaly map, the northern half of the study area has the majority of the anomaly zones followed by the southern part with the central portion having low Cu concentration values (Fig. 10d). Significant Pb anomalies exist across the area (Fig. 10e). However, the extreme north (near the gold prospect), central and south-western portions of the study area have very high anomaly values (Fig. 10e).

\subsection{Multi-element geochemical anomaly mapping}

Using the computed thresholds, geochemical halos, characterized by the existence of elevated contents of pathfinder elements related to Au mineralization were defined by applying the multi-element halo technique. Four multi-element anomaly maps were produced (Fig. 11a-d). Two of these were produced in consideration of Fe and $\mathrm{S}$ because of the presence of iron-sulfide ore minerals such as pyrite and the strong positive correlation that exists between Fe and $\mathrm{S}$ (Fig. 11a-b). The Fe-S-Cu anomaly map (Fig. 11a) shows anomalous zones dotted across the area. The Fe-S-Pb-As anomaly map similarly shows anomalous zones in the northern (near the Kunche gold prospect), central, and southern zones of the area under investigation (Fig. 11b). The multi-element map produced using the indicator elements for gold in the study area shows results similar to those of single element anomaly maps, with geochemical anomaly zones at the northern (near the Kunche gold prospect), central, and southern portions of the study area (Fig. 11c). Fig. 11(d) shows the (Pb+Cu+As+Ag)/Ti anomaly map which shows very high anomalies in the north-eastern, near-central, and south-western portions of the study area. Pb-Cu-As-Ag anomaly was divided by $\mathrm{Ti}$ anomaly to ascertain the influence of lithologies on the pathfinders. Since this map is similar to most of the earlier maps, lithologies, therefore, do not influence the anomalies.

\section{Discussion}

\subsection{Constraints from petrographic analysis}

The weathering of amphiboles such as hornblende $\left.\left(\mathrm{Ca}_{2}(\mathrm{Mg}, \mathrm{Fe})_{4} \mathrm{Al}(\mathrm{Si}, \mathrm{Al}) \mathrm{O}_{22}(\mathrm{OH}, \mathrm{F})_{2}\right)\right)$ contributes $\mathrm{Ca}$ and Fe contents to the laterites as well as stable phases of late stage quartz. Similarly, clinopyroxenes present such as diopside $\left(\mathrm{MgCaSi}_{2} \mathrm{O}_{6}\right)$ and orthopyroxene in the form of ferrosilite $\left(\mathrm{Fe}_{2} \mathrm{Si}_{2} \mathrm{O}_{6}\right)$ breakdown chemically invariably into quartz, releasing $\mathrm{Ca}$ and Fe during lateritization. This observation is corroborated by a similar observation made by Akintola et al. (2013) that hornblende is the major source of Fe and $\mathrm{Ca}$ and some trace elements in the regolith. Thus, the relatively high Fe and $\mathrm{Mg}$ contents

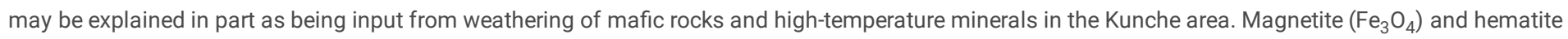
$\left(\mathrm{Fe}_{2} \mathrm{O}_{3}\right)$ in the laterites, which both crystallize in an environment with moderate oxygen levels, were originally formed via magmatic crystallization in the now metamorphosed igneous rocks and by hydrothermal fluid action within the metamorphic rocks (Reid, 2019). The rocks from which the laterites were formed in the Kunche area are no exceptions. Magnetite and hematite are persistent within the laterites due to their moderate resistance to weathering.

Sulphide-bearing minerals such as pyrite $\left(\mathrm{FeS}_{2}\right)$, associated with the mineralization in the area were precipitated under favorable conditions from the hydrothermal fluids that pervaded the host rocks within the Wa-Lawra Belt (Amponsah et al., 2015). The weathering of quartz veins released both Fe and S into the laterites. Sphalerite (ZnS) was formed by similar processes, but not the same event responsible for Au-rich quartz veins in the area as suggested by the correlation analysis. Thus, Zn within laterites was emplaced by the breakdown of sphalerite. This is supported by the findings of Langman and Moberly 
(2018) that the weathering of sphalerite releases $\mathrm{Zn}$ into the geochemical environment. Therefore, it can be inferred that $\mathrm{Pb}$, As, and $\mathrm{Cu}$ contents within the residual laterites are in part due to the presence of galena (PbS), arsenopyrite (AsFeS), and chalcopyrite (CuFeS 2 ), which have been reported in the Wa-Lawra Belt (Amponsah et al., 2015).

\subsection{Univariate outliers and element paragenetic occurrence}

The presence of several groups or populations is made evident by the occurrence of little distortions or changes in slope concentrations of $\mathrm{Cu}$, $\mathrm{Pb}$, Fe $\mathrm{Ag}$, $\mathrm{Au}$, and As as seen in the P-P plots (Fig. 7). There are also extreme concentration values from certain samples, which seem to be detached from the rest within the dataset. They are separated from the continuous concentration distribution of the elements in the P-P plots. Samples for which certain elemental concentrations do not follow the normal distribution are indicative of outliers (Sunkari et al., 2019). In exploration geochemistry, outliers are most probably the evidence of anomalies related to mineralization (Filzmoser et al., 2005). These outliers are also representative of different geochemical processes as stated earlier.

A good to strong positive correlation between elements shows paragenetic occurrence of the elements involved (Lapworth et al., 2012). Sunkari et al. (2019) revealed that such a correlation is indicative of similar geochemical processes which led to the distribution of the elements in the area. Their enrichment is therefore due to similar processes. Therefore, the good to strong positive correlation between $\mathrm{Fe}$ and $\mathrm{Cr}, \mathrm{S}$ and $\mathrm{Cr}, \mathrm{Mn}$ and $\mathrm{Cu}, \mathrm{Rb}$ and $\mathrm{Cu}, \mathrm{Zr}$ and $\mathrm{Sr}, \mathrm{Zn}$ and $\mathrm{As}$, $\mathrm{Cu}$ and $\mathrm{Au}, \mathrm{S}$ and $\mathrm{Ag}, \mathrm{Fe}$ and $\mathrm{S}, \mathrm{Mn}$ and $\mathrm{Rb}, \mathrm{Zr}$ and Ti, $\mathrm{Pb}$ and $\mathrm{Fe}, \mathrm{Pb}$ and $\mathrm{S}, \mathrm{S}$ and $\mathrm{Au}$, as well as $\mathrm{Ag}$ and $\mathrm{Au}$ (Table 3) indicates paragentic occurrence of these elements. It is interpreted that similar regolith geochemical processes in the study area account for the dispersion and mobilization of these elements in the residual laterites.

However, Simmonds et al. (2017) mentioned that a moderate to strong negative correlation is indicative of non-paragenetic occurrence. This means that the moderate to strong negative correlations between $\mathrm{Mn}$ and $\mathrm{Ni}$, $\mathrm{Ca}$ and $\mathrm{Ni}$, Fe and $\mathrm{Rb}, \mathrm{Ni}$ and $\mathrm{Rb}, \mathrm{Cr}$ and $\mathrm{Sr}$, Ni and $\mathrm{Sr}$, Mn and $\mathrm{Zr}$, $\mathrm{Cu}$ and $\mathrm{Zr}$, $\mathrm{Ca}$ and $\mathrm{Zn}$, as well as $\mathrm{Ca}$ and As (Table 3) were due to different regolith geochemical processes together with dispersion and concentration of elements by leaching of elements during events of lateritization and dilution or enrichment of elements during intermixing of surface or groundwater in the area.

Also, the strong positive correlation between $\mathrm{Au}$ and $\mathrm{Ag}, \mathrm{Cu}$, and $\mathrm{S}$ is directly related to the occurrence of gold in the area. Au correlates weakly and positively with $\mathrm{Fe}, \mathrm{Pb}$, and $\mathrm{As}$ (Table 3), implying that $\mathrm{Fe}, \mathrm{Pb}$, and $\mathrm{As}$ could have occurred with $\mathrm{Au}$, however, they were subsequently redistributed by multiple regolith geochemical processes (Sunkari et al., 2019). The negative negligible correlation between Au and $\mathrm{Zn}$ is probably due to complex regolith geochemical processes.

\subsection{Identification of pathfinder elements from multivariate statistical analyses}

From the factor analysis, the CLR transformed dataset reveals that factor 1 with element associations involving Fe-S-Co-Pb and factor 2 with element associations of Mn-Cu-Rb-Au are similar to cluster 1 from the HCA with multi-element associations of $\mathrm{Au}, \mathrm{Fe}, \mathrm{S}, \mathrm{Ag}, \mathrm{Pb}, \mathrm{Mn}, \mathrm{Cr}, \mathrm{Co}, \mathrm{Ni}$, and Cu. This similarity confirms the inferred sulfide ore minerals, mafic host rocks, wall rocks, and hydrothermal fluid inputs (Sunkari et al., 2019; Fagbohun et al., 2021; Mvile et al., 2021). Factor 4 from the factor analysis with element associations of Ti-Cr-Sr-Zr is similar to cluster 2 from the HCA with element associations of Ti-Sr-Zr-Ca. This similarity also confirms the detrital material and wall rock inputs of the elements involved. Cluster 3 from HCA with element associations of Zn-As-Y-Rb is similar to factor 5 from the factor analysis with element associations of $\mathrm{Zn}$-As-Ca. This similarity also further validates the hydrothermal solution and wall rocks input of the elements involved (Fagbohun et al., 2021). Considering all these, using cluster 1 of the CLR transformed data from the HCA is the best element grouping followed by cluster 3 when identifying pathfinder elements of gold in the area. From this, $\mathrm{Cu}, \mathrm{Pb}, \mathrm{Ag}$, and $\mathrm{As}$ may be regarded as the elemental cluster related to the occurrence of gold in the Kunche area. As stated from the correlation analysis, there is a positive correlation between $\mathrm{Cu}$, $\mathrm{Pb}$, $\mathrm{Ag}, \mathrm{As}$, and $\mathrm{Au}$. $\mathrm{Zn}$ is on the other hand unrelated to Au occurrence in the area due to its negative negligible correlation with $\mathrm{Au}(\mathrm{r}=-0.02)$. Therefore, $\mathrm{Cu}, \mathrm{Pb}, \mathrm{Ag}$, and As can be identified as the pathfinders of Au in the area.

\subsection{Geological and mineral exploration implications}

Several studies have effectively used trace elements of residual regolith materials to determine the underlying lithologies of a mineralized terrane (Sadeghi et al., 2005; Vos et al., 2009; Mvile et al., 2021). The trace element composition of mafic-ultramafic lithologies such as basalts, metavolcanics, diorites and granodiorites are explicitly different from that of felsic lithologies like granites and can be easily deciphered from trace element geochemical data of residual regolith materials. Accordingly, $\mathrm{Ni}, \mathrm{Co}, \mathrm{Cr}$, and $\mathrm{V}$ are commonly associated with weathered residual regolith materials of mafic-ultramafic lithologies, whereas $\mathrm{Ca}, \mathrm{Rb}, \mathrm{Sr}$, and $\mathrm{Y}$ are usually observed in weathered residual regolith materials of felsic lithologies (Dampare et al., 2008; Abu and Sunkari, 2020; Abu et al., 2020). Thus, the two set of trace elements can be used as proxies for bedrock mapping in complex regolith terranes. The Wa-Lawra Belt is a typical greenstone belt dominated by Birimian metavolcanics and volcaniclastics, Birimian metasediments and some intrusive granitoids (Baratoux et al., 2011; Amponsah et al., 2015; Sunkari and Zango, 2018). In this regard, the elemental association of Fe-S-Pb-Mn-Cr-Co-Ni-Cu-Ag-Au observed in cluster 1 of the transformed data (Fig. 9b) indicates the presence of mafic-ultramafic basement lithologies and is consistent with the findings of Mvile et al. (2021) in a similar greenstone belt in East Africa. Moreover, the association of Au in this element cluster indicates the control that mafic-ultramafic lithologies in the WaLawra Belt have on gold mineralization in the area. The elemental associations of Ca-Ti-Zr-Sr and Rb-Y-Zn-As in cluster 2 and 3 , respectively of the transformed data can be used as proxies for felsic-intermediate basement lithologies in the area.

According to Waller et al. (2012), there is commercial gold mineralization in the Wa-Lawra Belt associated with the volcaniclastics, however, efforts to explore and exploit this gold resource have been terminated over the years due to lack of success. Sunkari et al. (2019) indicated that most companies exploring for gold in the belt use methods drawn from those used in the southern parts of Ghana without consideration of the fact that there is a contrast between the climatic conditions prevailing in northern and southern parts of the country. Savannah climate exists in northern Ghana leading to a landscape that is a deeply weathered terrane with abundant laterites. This implies that how elements are mobilized and/or dispersed by different geochemical processes in northern

Page $12 / 21$ 
Ghana varies from that of southern Ghana and hence, different methods of mineral exploration, as well as different methods of interpretation of geochemical signatures are required in the Wa-Lawra Belt.

Nude et al. (2012) and Sunkari et al. (2019) have stated, in such deeply weathered terrane, laterites are the best material to sample for geochemical surveys carried out to determine the indicator elements for gold. Sampling lateritic duricrusts in such cases will produce geochemical patterns that are representative of the rocks from which these laterites were derived. On the other hand, transported laterites, which were formed in depositional/mixed and transitional environments/terranes may have compositions that are erratic and not related to mineralization, hence sampling transported laterites is likely not to produce a geochemical pattern representative of the sampling environment (Anand, 2001). For these reasons, Sunkari et al. (2019) concluded that areas dominated by residual laterites (on hills and plateaus) are the areas where the geochemical anomalies are mostly located and that the prospecting of gold should be focused on those areas for optimal operations.

From this study, the multi-element patterns of only residual laterites reveal geochemical anomalies that are mainly restricted to the northern and southern parts of the study area, corresponding to hills and plateaus. Gold prospection should therefore focus on the hills and plateaus within the complex regolith terrane of the Wa-Lawra Belt, where conventional exploration techniques may not be successful. This study also proves that residual laterites are the best sampling media in such deeply weathered terranes.

\section{Conclusions}

The following conclusions are drawn from the current study;

- This study focused on only residual laterites obtained from areas where the land surface is elevated such as hills, ridges, and plateaus in the study area. Petrographic studies reveal amphibole, clinopyroxene, quartz, magnetite, hematite, goethite, pyrite, and sphalerite.

- Box and Whisker Plots show Mn and S as the most dominant and least dominant elements within the residual laterites in the area, respectively. P-P plots reveal that the multi-element geochemical data obtained from these laterites stemmed from more than one population as a result of different geological processes, made evident by kinks in the slopes of the plots for selected elements.

- Spearman's correlation, factor analysis and hierarchical cluster analysis identified $\mathrm{Pb}, \mathrm{Cu}, \mathrm{Ag}$, and $\mathrm{As}$ to be directly related to the occurrence of $\mathrm{Au}$ in the Kunche area.

- $\mathrm{Pb}, \mathrm{Cu}, \mathrm{Ag}$, and $\mathrm{As}$ can be therefore considered as the elemental cluster related to the occurrence of $\mathrm{Au}$ in the Kunche area. This implies that $\mathrm{Cu}, \mathrm{Pb}, \mathrm{Ag}$, and As are the indicator elements of gold in the Wa-Lawra Belt. This finding is not different from those of earlier studies, where soil/laterites from mixed sources were used.

- Therefore, using residual laterites as well as laterites from mixed sources will likely produce similar results in relation to pathfinder elements in the WaLawra Belt.

- The delineation of the single and multi-element halos of these elements revealed that geochemical anomalies are restricted to the northern and southern portions of the study area, on the hills, ridges, and plateaus. In the northern part, the geochemical anomaly is near a gold prospect. Gold prospecting activities must therefore focus on the hilly, ridgetop, and plateau areas within the Wa-Lawra Belt where residual laterites dominate.

\section{Declarations}

\section{Declaration of Competing Interests}

The authors declare that they have no known competing financial interests or personal relationships that could have appeared to influence the work reported in this paper.

\section{Acknowledgements}

This study is part of the Bachelor thesis of the second author at the University of Mines and Technology, Tarkwa, Ghana. The authors wish to thank Azumah Resources Limited, Ghana for their immense contribution to the acquisition of the samples and data used for this study. Special thanks also go to the Petrology Laboratory Technician of the University of Mines and Technology, Tarkwa, Ghana, Mr. Abdul-Rahman Abdullah for his relentless support during the preparation of the thin and polished sections.

\section{References}

1. Abu, M., Sunkari, E.D., 2020. Geochemistry and petrography of beach sands along the western coast of Ghana: implications for provenance and tectonic settings. Turkish Journal of Earth Sciences, 29(2), 363-380. https://doi.org/10.3906/yer-1903-8.

2. Abu, M., Sunkari, E.D., Gürel, A., 2020. Paleocurrent analysis, petrographic, geochemical and statistical appraisal of Neoproterozoic siliciclastic sediments, NE Voltaian Basin, Ghana: a multidisciplinary approach to paleogeographic reconstruction. Journal of Sedimentary Environments 5(2), $199-218$. https://doi.org/10.1007/s43217-020-00016-5.

3. Akintola, A.I., Olorunfemi, A.O., Bankole, S.I., Omotoye, S.J., Ajayi, B.O., 2013. Petrography and Geochemical evaluation of major and trace element concentrations in the stream sediments of Itagunmodi and its environs, Southwestern, Nigeria. Journal of Earth Sciences and Geotechnical Engineering $3(4), 1-24$. 
4. Amponsah, P.O., Salvi, S., Béziat, D., Siebenaller, L., Baratoux, L., Jessell, M.W., 2015. Geology and Geochemistry of the Shear Hosted Julie Deposit, NW Ghana. Journal of African Earth Sciences 112, 505-523. https://dx.doi.org/10.1016/j.jafrearsci.2015.06.013.

5. Anand, R.R., 2001. Evolution, classification and use of ferruginous regolith materials in gold exploration, Yilgarn Craton, Western Australia. Geochemistry: Exploration, Environment, Analysis 1, 221-236.

6. Anand, R.R., Pain, M., 2002. Regolith Geology of the Yilgarn Craton and its Implications to Exploration. Australian Journal of Earth Sciences 49 , 3-164. https://dx.doi.org/10.1046/j.1440-0952.2002.00912.x.

7. Anand, R.R., Wildman, J.E., Varga, Z.S., Phang, C., 2001. Regolith evolution and geochemical dispersion in transported and residual regolith-Bronzewing gold deposit. Geochemistry: Exploration, Environment, Analysis 1(3), 265-276.

8. Arhin, E., 2013. Use of Regolith Geochemistry to Delineate Gold Mineralization under cover: a case study in the Lawra Belt, NW Ghana. Unpublished PhD Thesis, Department of Geology, University of Leicester, UK, 286 pp.

9. Arhin, E., 2014. Regolith Geochemistry and Hidden Deposits, Lambert Academic Publishing, Germany, 269 pp.

10. Arhin, E., Jenkin, G.R., Cunningham, D., Nude, P., 2015. Regolith mapping of deeply weathered terrain in savannah regions of the Birimian Lawra Greenstone Belt, Ghana. Journal of Geochemical Exploration 159, 194-207.

11. Arhin, E., Nude, P., 2009. Significance of Regolith Mapping and Its Implication for Gold Exploration in Northern Ghana: A Case Study at Tinga and Kunche. Geochemistry: Exploration, Environment and Analysis 9, 63-69. http://dx.doi.org/10.1144/1467-7873/08-189.

12. Baratoux, L., Metelka, V., Naba, S., Jessell, M.W., Grégoire, M., Ganne, J., 2011. Juvenile Paleoproterozoic Crust Evolution during the Eburnean Orogeny (2.2-2.0 Ga), Western Burkina Faso. Precambrian Research 191(1-2), 18-45. https://doi.org/10.1016/j.precamres.2011.08.010.

13. Block, S., Jessell, M.W., Ailleres, L., Baratoux, L., Bruguier, O., Zeh, A., Bosch, D., Caby, R., Mensah, E., 2015. Lower Crust Exhumation during Paleoproterozoic (Eburnean) Orogeny, NW Ghana, West African Craton: Interplay of Coeval Contractional Deformation and Tensional Gravitational Collapse. Precambrian Research 274, 82-109.

14. Bourman, R.P., Buckman, S., Chivas, A.R., Ollier, C.D., Price, D.M., 2020. Ferricretes at Burringurrah (Mount Augustus), Western Australia: proof of lateral derivation. Geomorphology 354, 107017.

15. Bourman, R.P., Ol1ier, C.D., 2002. A Critique of the Schel1mann Paleosols, Pre-Quaternary Definition and Classification of Laterite. Catena 47(2), 117-131.

16. Butt, C.R.M., Lantern, M.J., Anand, R.R., 2000. Evolution of Regolith and Landscapes in Deeply Weathered Terrain - Implications for Geochemical Exploration. Ore Geology Reviews 16(3-4), 167-183.

17. Dampare, S.B., Shibata, T., Asiedu, D.K., Osae, S., Banoeng-Yakubo, B., 2008. Geochemistry of Paleoproterozoic metavolcanic rocks from the southern Ashanti volcanic belt, Ghana: Petrogenetic and tectonic setting implications. Precambrian Research 162(3-4), 403-423.

18. Debrah, T., 2013. Identifying Pathfinder Elements for Gold in A Multi-Element Soil Geochemical Data, Owere Mines Limited, Konongo. Unpublished BSc. Project Work, University of Mines and Technology, pp. 3-20.

19. Deng, J., Wang, Q., Yang, L., Wang, Y., Gong, Q., Liu, H., 2010. Delineation and explanation of geochemical anomalies using fractal models in the Heqing area, Yunnan Province, China. Journal of Geochemical Exploration 105(3), 95-105. https://doi.org/10.1016/j.gexplo.2010.04.005.

20. Duarte, I.M.R., 2002. Residual Soils of Granitoid Rocks to South of the Tagus River. Geological and Geotechnical Characteristics. Unpublished Doctoral Dissertation, University of Évora, Évora, Portugal.

21. Fagbohun, B.J., Bamisaiye, O.A., Ayoola, F.J., Omitogun, A.A., Adeoti, B., 2021. Identifying geochemical anomalies and spatial distribution of gold and associated elements in the Zuru Schist Belt, northwest Nigeria. Arabian Journal of Geosciences 14(6), 1-20. https://doi.org/10.1007/s12517-021-068287.

22. Feybesse, J.L., Billa M., Guerrot C., Duguey E., Lescuyer, J., Milési, J.P. and Bouchot, V., 2006. The Paleoproterozoic Ghanaian Province: Geodynamic Model and Ore Controls, Including Regional Stress Modeling. Precambrian Research 149(3-4), 149-196.

23. Filzmoser, P., Garrett, R.G., Reimann, C., 2005. Multivariate outlier detection in exploration geochemistry. Computers \& geosciences 31(5), $579-587$.

24. Gao, Y., Chik, A.B.R., 2013. A Multiple Regression Analysis on Influencing Factors of Urban Services Growth in China. Technology and Investment 4, $1-5$. https://doi.org/10.4236/TI.2013.41B001.

25. Ghezelbash, R., Maghsoudi, A., Daviran, M., Yilmaz, H., 2019. Incorporation of principal component analysis, geostatistical interpolation approaches and frequency-space-based models for portraying the Cu-Au geochemical prospects in the Feizabad district, NW Iran. Geochemistry 79(2), 323-336. https://doi.org/10.1016/j.chemer.2019.05.005.

26. Griffis, J., Barning, K., Agezo, F.L., Akosa, F., 2002. Gold deposits of Ghana, Mineral Commission, Accra, Ghana, 432 pp.

27. Helba, H.A., Khalil, K.I., Mamdouh, M.M., Khalek, I.A.A., 2020. Zonation in primary geochemical haloes for orogenic vein-type gold mineralization in the Quartz Ridge prospect, Sukari gold mine area, Eastern Desert of Egypt. Journal of Geochemical Exploration 209, 106378.

28. Langman, J.B., Moberly, J.G., 2018. Weathering of a mined quartz-carbonate, galena-sphalerite ore and release and transport of nanophase zinc carbonate in circumneutral drainage. Journal of Geochemical Exploration 188, 185-193.

29. Lapworth, D.J., Knights, K.V., Key, R.M., Johnson, C.C., Ayoade, E., Adekanmi, M.A., Arisekola, T.M., Okunlola, O.A., Backman, B., Eklund, M., Everett, P.A., 2012. Geochemical mapping using stream sediments in west-central Nigeria: Implications for environmental studies and mineral exploration in West Africa. Applied Geochemistry 27(6), 1035-1052.

30. Lermi, A., Sunkari, E.D., 2020. Geochemistry, risk assessment, and Pb isotopic evidence for sources of heavy metals in stream sediments around the Ulukışla Basin, Niğde, southern Turkey. Turkish Journal of Earth Sciences 29(7), 1167-1188.

31. Mazzucchelli, R.H., James, C.H., 1966. Arsenic as a guide to gold mineralization in laterite covered areas of Western Australia. Inst. Min. Metall. Trans. 75, 286-294. 
32. McClenaghan, M.B., Parkhill, M.A., Pronk, A.G., Seaman, A.A., McCurdy, M.W., Leybourne, M.I., 2017. Indicator mineral and geochemical signatures associated with the Sisson W-Mo deposit, New Brunswick, Canada. Geochemistry: Exploration, Environment, Analysis 17(4), $297-313$.

33. McQueen, K.G., McRae, A., 2004. New ways to explore through the regolith in western New South Wales. Pacrim 2004 Congress Proceedings, The Australian Institute of Mining and Metallurgy, Melbourne, pp. 232-238.

34. Micó, C., Peris, M., Recatala, L., Sanchez, J., 2006. Assessing heavy metal sources in agricultural soils of a European Mediterranean area by multivariate analysis. Chemosphere 65(5), 863-872.

35. Mvile, B.N., Abu, M., Kalimenze, J., 2021. Trace Elements Geochemistry of In Situ Regolith Materials and Their Implication on Gold Mineralization and Exploration Targeting, Dodoma Region, East Africa. Mining, Metallurgy \& Exploration 38(5), 2075-2087.

36. Nude, P.M., Asigri, J.M., Yidana, S.M., Arhin, E., Foli, G., Kutu, J.M., 2012. Identifying Pathfinder Elements for Gold in Multi-Element Soil Geochemical Data from the Wa-Lawra Belt, Northwest Ghana: A Multivariate Statistical Approach. International Journal of Geosciences 3(1), $62-70$. http://dx.doi.org/10.4236/ijg.2012.31008.

37. Rate, A.W., 2018. Multielement geochemistry identifies the spatial pattern of soil and sediment contamination in an urban parkland, Western Australia. Science of the Total Environment 627, 1106-1120.

38. Reid, A., 2009. The Olympic Cu-Au Province, Gawler Craton: Review of the Lithospheric Architecture, Geodynamic Setting, Alteration Systems, Cover Successions, and Prospectivity. Minerals 9(6), 371.

39. Reimann, C., Filzmoser, P., Garrett, R.G., 2005. Background and threshold: a critical comparison of methods of determination. Science of the Total Environment 346(1-3), 1-16.

40. Reis, A.P., Sousa, A.J., Fonseca, E.C., 2001. Soil Geochemical Prospecting for Gold at Marrancos (Northern Portugal). Journal of Geochemical Exploration 73(1), 1-10.

41. Riedinger, N., Brunner, B., Krastel, S., Arnold, G.L., Wehrmann, L.M., Formolo, M.J., Lyons, T.W., 2017. Sulfur cycling in an iron oxide-dominated, dynamic marine depositional system: the Argentine continental margin. Frontiers in Earth Science 5, 33. https://doi.org/10.3389/feart.2017.00033.

42. Sabbaghi, H., Tabatabaei, S.H., 2020. A Combinative Knowledge-Driven Integration Method for Integrating Geophysical Layers with Geological and Geochemical Datasets. Journal of Applied Geophysics 172, 103915.

43. Sadeghi, M., Billay, A., Carranza, E.J.M., 2015. Analysis and mapping of soil geochemical anomalies: Implications for bedrock mapping and gold exploration in Giyani area, South Africa. Journal of Geochemical Exploration 154, 180-193.

44. Scott, K.M., Pain, C.F., 2008. Regolith Science, Springer CSIRO Publishing, Australia, 472 pp.

45. Simmonds, V., Jahangiryar, F., Moazzen, M., Ravaghi, A., 2017. Distribution of base metals and the related elements in the stream-sediments around the Ahar area (NW Iran) and their implications. Chemie der Erde - Geochemistry 77(3), 429-441.

46. Sunkari, E.D., Abu, M., Zango, M.S., Wani, A.M.L., 2020. Hydrogeochemical characterization and assessment of groundwater quality in the KwahuBombouaka Group of the Voltaian Supergroup, Ghana. Journal of African Earth Sciences 169, 103899.

47. Sunkari, E.D., Appiah-Twum, M., Lermi, A., 2019. Spatial distribution and trace element geochemistry of laterites in Kunche area: Implication for gold exploration targets in NW, Ghana. Journal of Africa Earth Sciences 158, 103519 https://doi.org/10.1016/j.jafrearsci.2019.103519.

48. Sunkari, E.D., Zango, M.S., 2018. Preliminary investigation of the geologic controls of graphite mineralization and exploration potential of the Wa-Lawra Belt: Implications for Kambale graphite deposit. J. Environ. Earth Sci 8(3), 77-89.

49. Taylor, G., Eggleton, R.A., 2001. Regolith Geology and Geomorphology. John Wiley \& Sons Ltd, New York, Geological Magazine $138(6), 727$.

50. Vos, I.M.A., Bierlein, F.P., Standing, J.S., Davidson, G., 2009. The geology and mineralisation at the Golden Pride gold deposit, Nzega Greenstone Belt, Tanzania. Mineralium Deposita 44(7), 751. https://doi.org/10.1007/s00126-009-0245-3.

51. Waller, C., Franey, N., Hodgson, S., Widenbar, L., 2012. Nl-43-101 Technical Report for Azumah Resources LTD, Wa Gold Project, Ghana, 114 pp.

52. Wane, O., Ouologuem, A. B., N'diaye, I., Dao, O., Yossi, M., 2021. Petro-Structural Study of the Paleoproterozoic Formations of the Faboula Gold Deposit (Bougouni-Kékoro Basin, Leo-Man Shield). Open Journal of Geology 11(4), 105.

53. Widdowson, M., 2009. Encyclopedia of Paleoclimatology and Ancient Environments", Encyclopedia of Earth Sciences Series, Gornitz V. (ed.), Springer Publishing, Dordrecht, https://doi.org/10.1007/978-1-4020-4411-3_127.

54. Zhao, J., Chen, S., Zuo, R., 2015. Identifying geochemical anomalies associated with Au - Cu mineralization using multifractal and artificial neural network models in the Ningqiang district, Shaanxi, China. Journal of Geochemical Exploration 164, 54-64. https://doi.org/10.1016/j.gexplo.2015.06.018.

55. Zuo, R., 2011. Identifying geochemical anomalies associated with $\mathrm{Cu}$ and $\mathrm{Pb}-\mathrm{Zn}$ skarn mineralization using principal component analysis and spectrum-area fractal modeling in the Gangdese Belt, Tibet (China). Journal of Geochemical Exploration 111(1-2), 13-22.

\section{Figures}




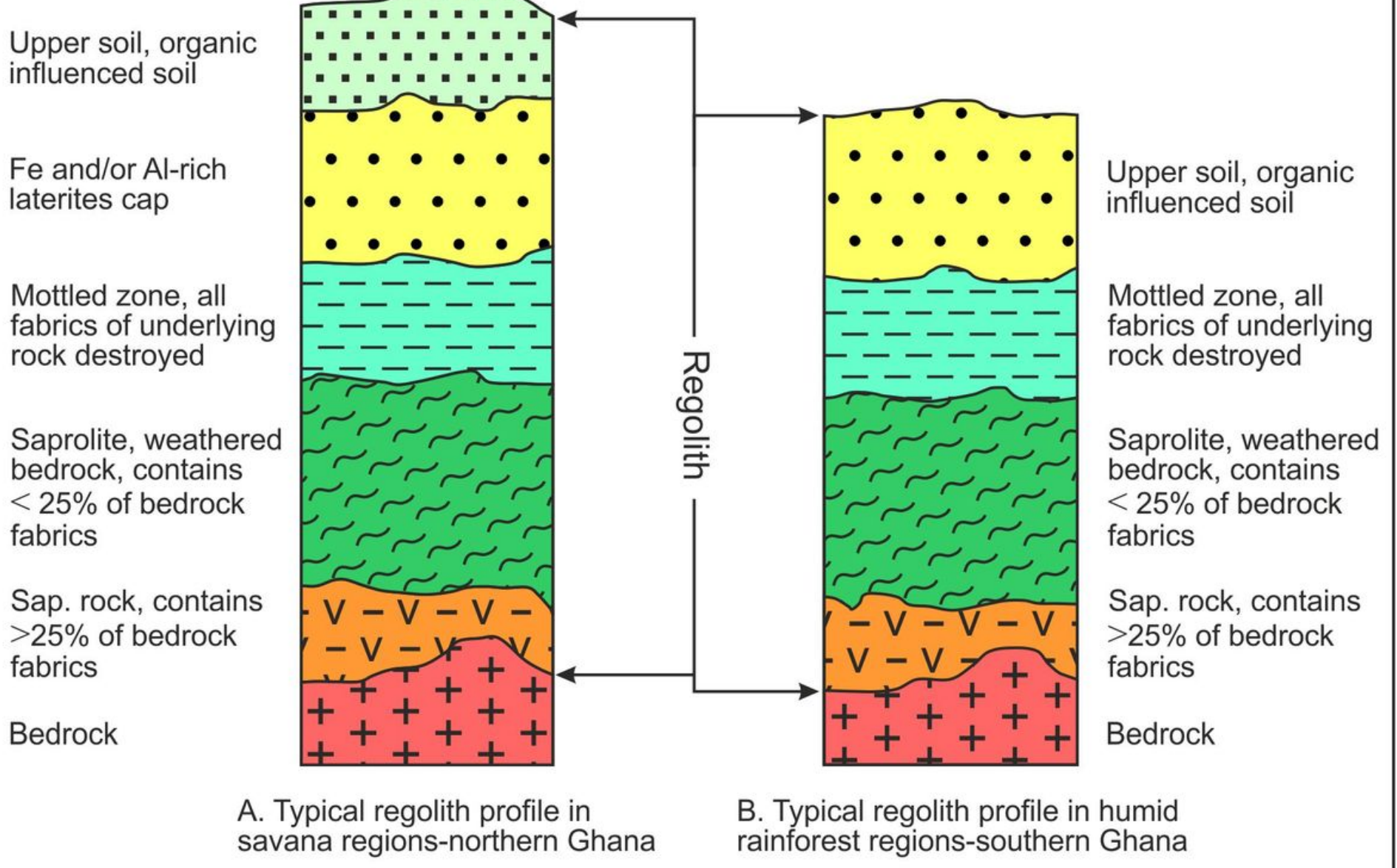

Figure 1

Typical regolith profiles in Savannah and rainforest regions of Ghana (after Arhin and Nude, 2009).
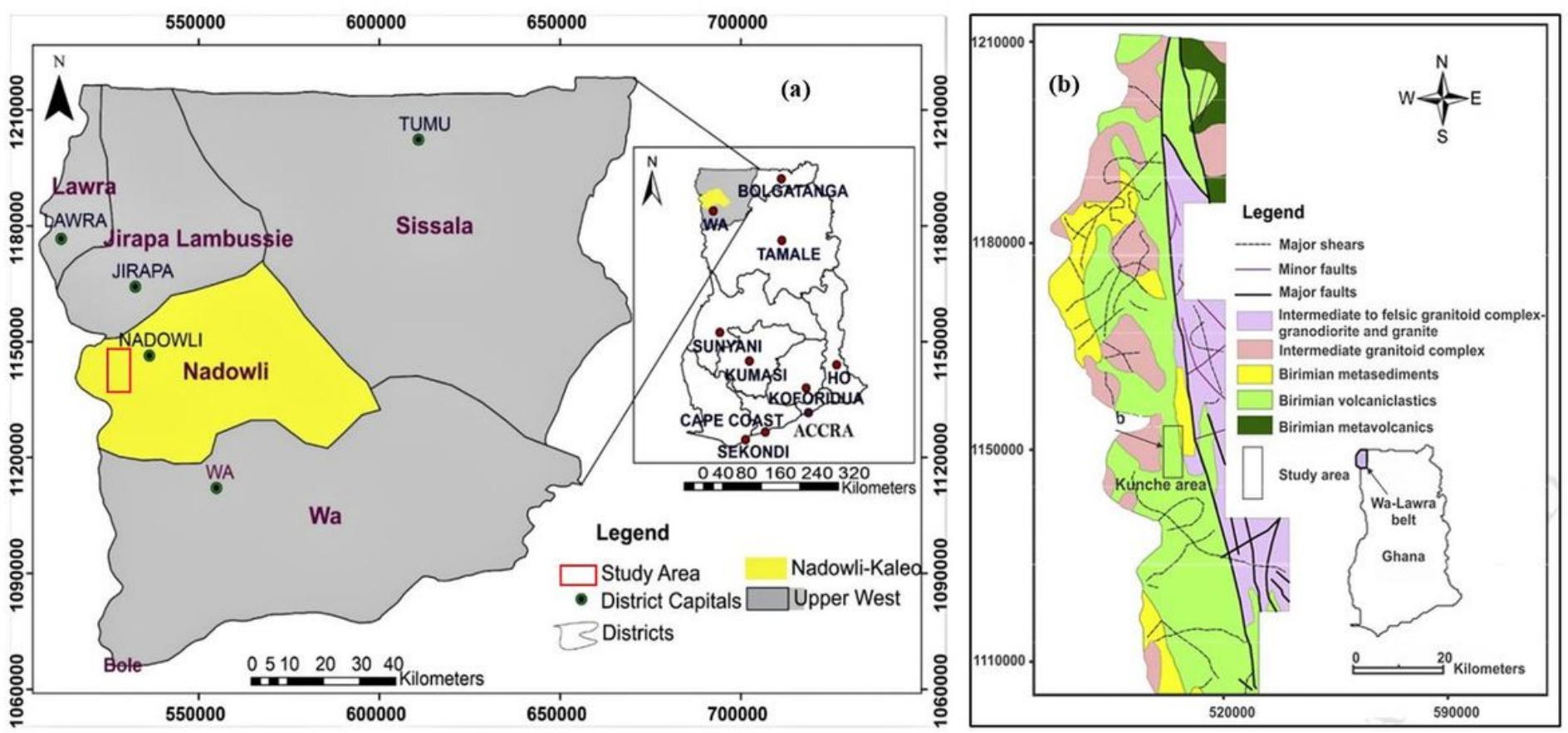

Figure 2 
(a) Administrative map of the Upper West Region showing the study area within the Nadowli-Kaleo District and (b) Geological map of the Wa-Lawra Belt showing the dominance of Birimian volcaniclastics in the Kunche area (after Arhin et al., 2015).

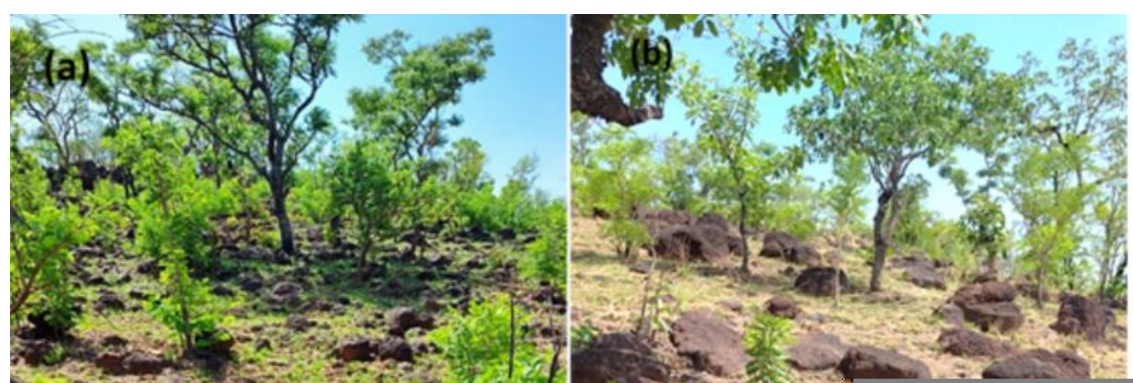

\section{Figure 3}

Photographs of lateritic duricrusts on hills in the Kunche area.

त्ये

\section{Figure 4}

Photomicrograph images of thin sections from the residual laterites showing (a) Amphibole, clinopyroxene, quartz, goethite and hematite, (b) Deformed amphiboles with recrystallized quartz and clinopyroxene, (c) Granoblastic texture, (d) Fractures within clinopyroxene lined with quartz, (e) Rims of amphibole around clinopyroxene, and (f) Orthopyroxene, hornblende, quartz and an ppaque mineral (Qtz = Quartz, Amp = Amphibole, $\mathrm{Hbl}=\mathrm{Hornblende}, \mathrm{Cpx}=$ Clinopyroxene, Opx = Orthopyroxene, Hem = Hematite, Gth = Goethite) . 

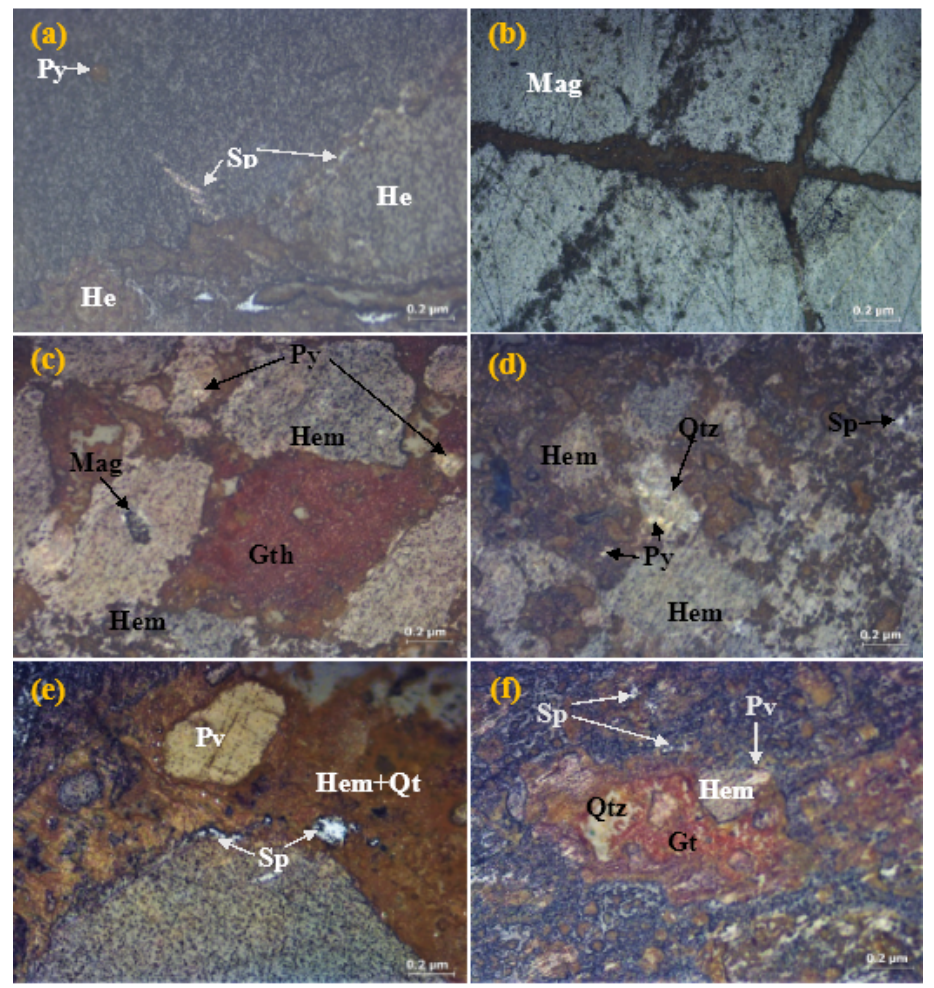

\section{Figure 5}

Photomicrograph images of polished sections from the residual laterites showing (a) Sphalerite in hematite, (b) Subhedral tabular magnetite masses, (c) Magnetite in hematite with goethite, (d) Pyrite in sheared quartz and sphalerite blebs in hematite, (e) Deformed pyrite and hematite with selvages of sphalerite, and (f) Pyrite replaced by hematite, and hematite replaced by goethite with recrystallized quartz and sphalerite blebs (Qtz = Quartz, Py = Pyrite, Hem = Hematite, $\mathrm{Sp}=$ Sphalerite, $\mathrm{Mag}=$ Magnetite, $\mathrm{Gth}=$ Goethite) .

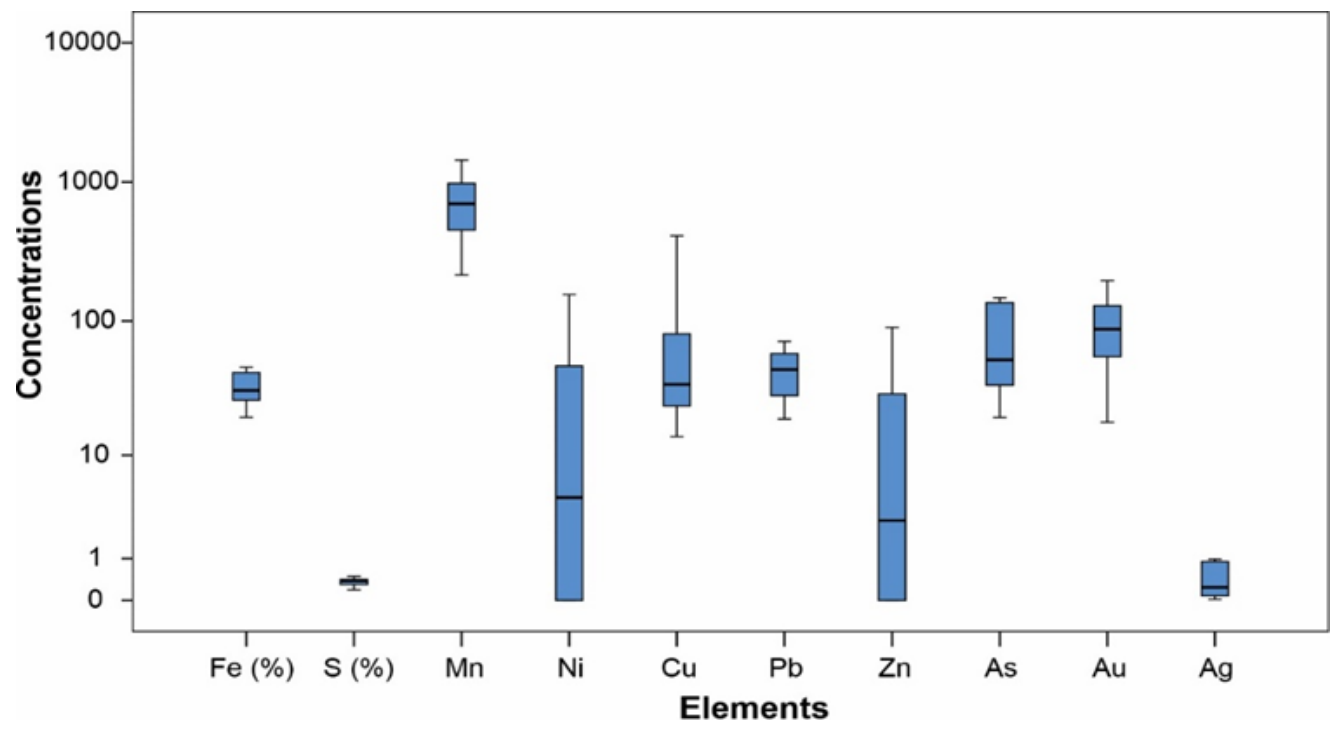

\section{Figure 6}

Box and whisker plots of $\mathrm{Fe}, \mathrm{S}, \mathrm{Mn}, \mathrm{Ni}, \mathrm{Cu}, \mathrm{Pb}, \mathrm{Zn}, \mathrm{As}, \mathrm{Au}$ and $\mathrm{Ag}$ (concentrations of $\mathrm{Fe}$ and $\mathrm{S}$ in \%, $\mathrm{Au}$ in ppb, and the rest in ppm).

\section{Figure 7}

P-P plots for (a) Fe, (b) Pb, (c) Ag, (d) As, (e) Cu and (Fe) Au. 

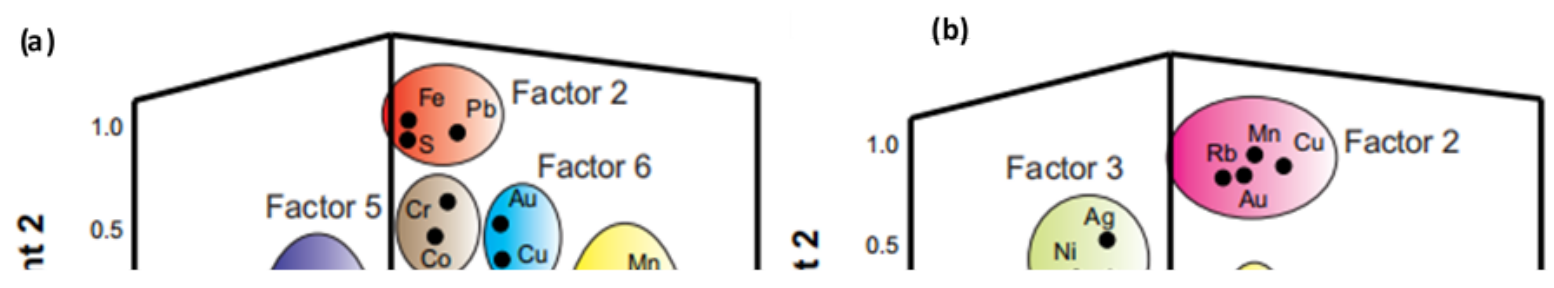

Figure 8

(a) Factor analysis plot of the untransformed data rotated in space and (b) Factor analysis plot rotated in space for centered log-ratio transformed dataset.
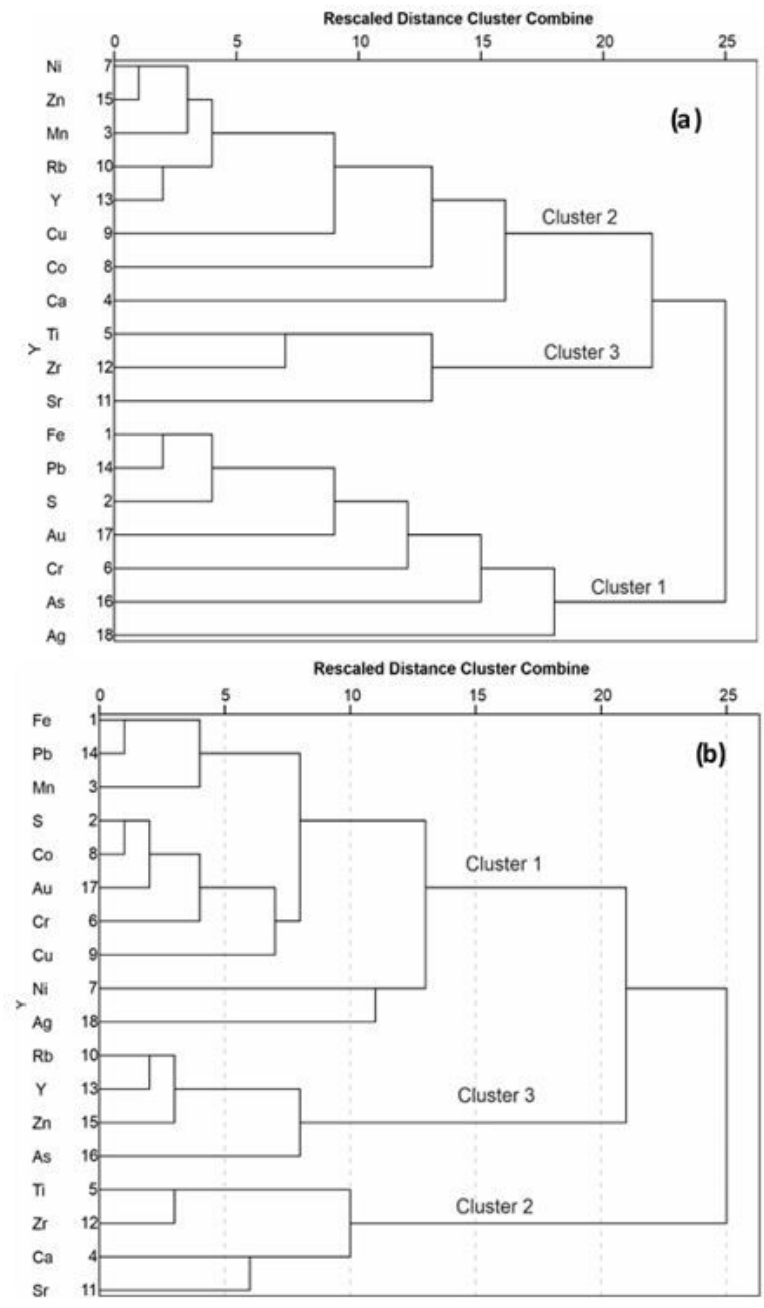

Figure 9 
(a) Dendrogram for untransformed dataset indicating three multi-element clusters and (b) Dendrogram for transformed dataset indicating three multi-element clusters.
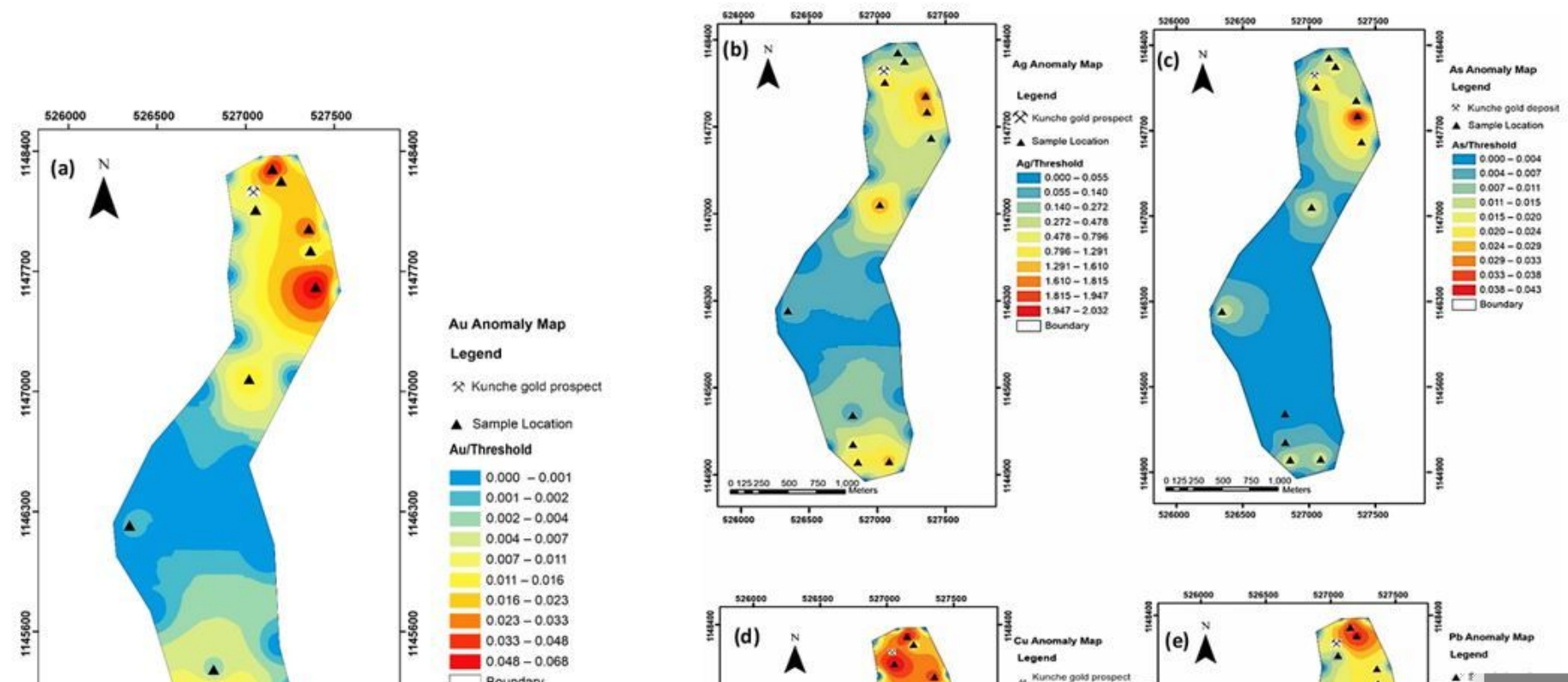

\section{Figure 10}

Single element geochemical anomaly maps for (a) Au, (b) Ag, (c) As, (d) Cu and (e) Pb with deep yellow to deep red areas as potential targets. 

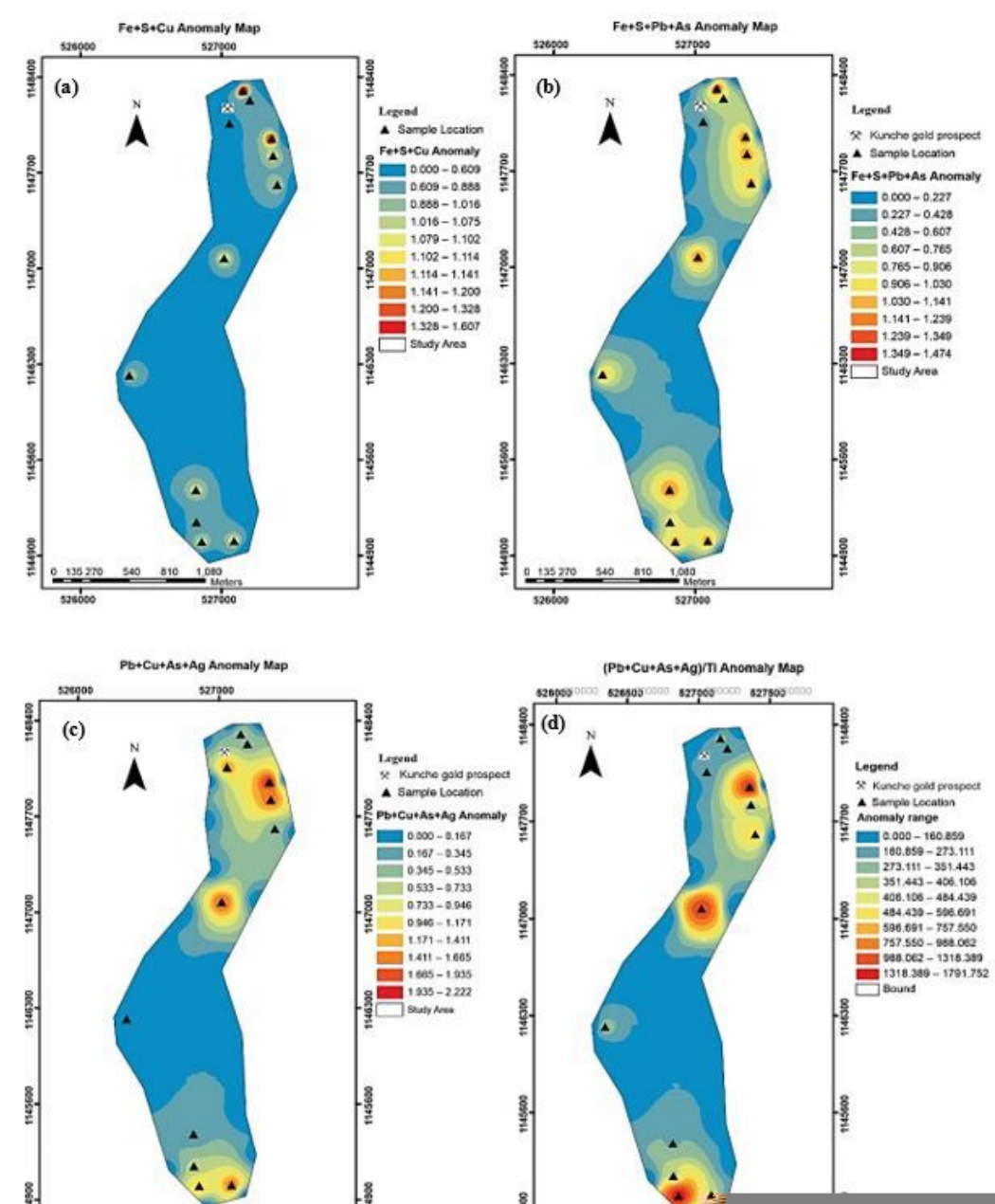

\section{Figure 11}

Multi-element geochemical anomaly maps showing prospective gold areas in deep yellow to deep red, using multi element halo technique for (a) Fe+S+Cu, (b) $\mathrm{Fe}+\mathrm{S}+\mathrm{Pb}+\mathrm{As}$, (c) $\mathrm{Pb}+\mathrm{Cu}+\mathrm{As}+\mathrm{Ag}$ and $(\mathrm{d})(\mathrm{Pb}+\mathrm{Cu}+\mathrm{As}+\mathrm{Ag}) / \mathrm{Ti}$. 